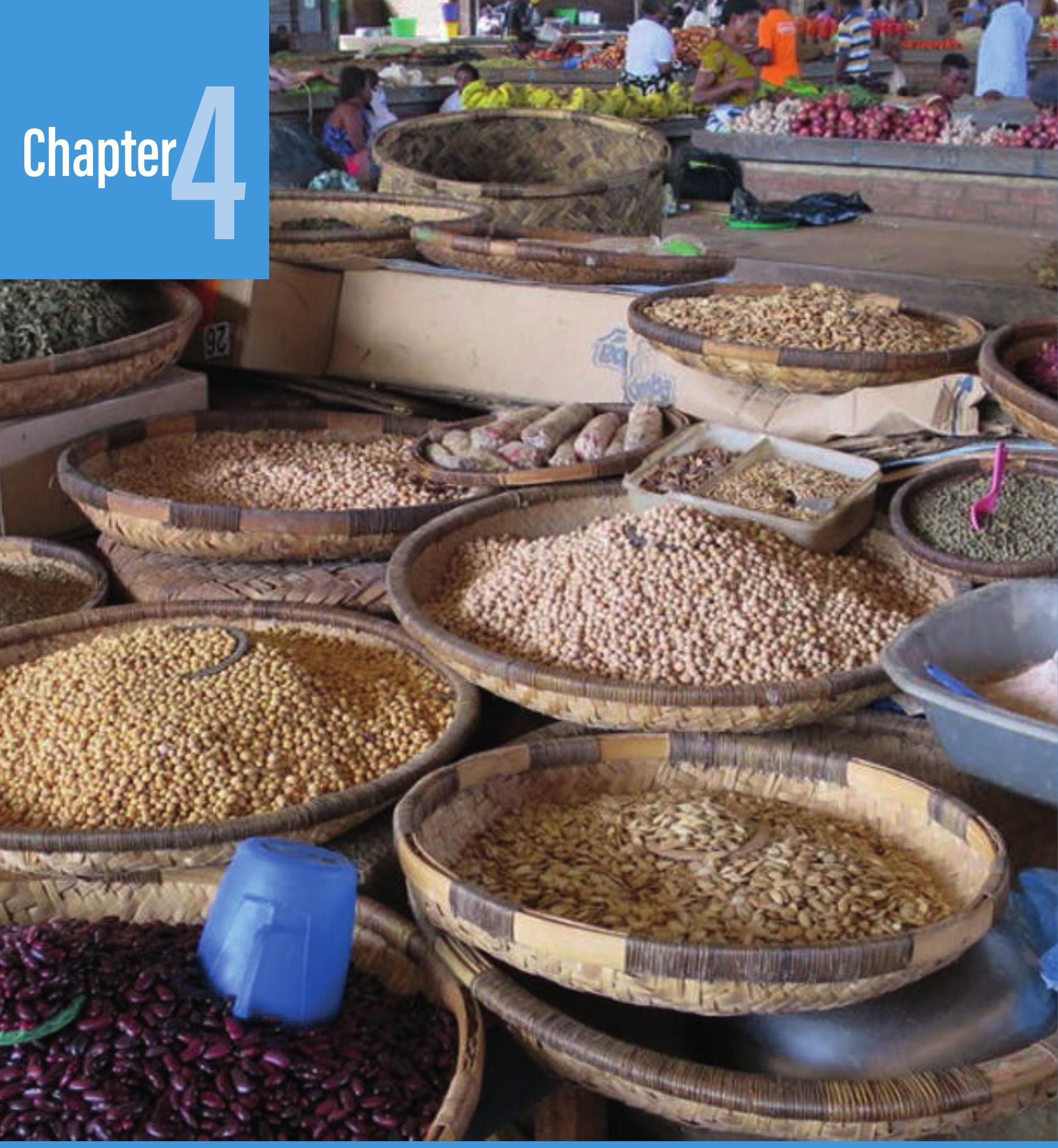

\title{
Competitiveness of African Countries in Agrifood Products
}

Antoine Bouët, Anatole Goundan, and Chahir Zaki 


\section{Introduction}

In the 2019 AATM report (Chapter 4), we studied the competitiveness of several African exportoriented commodity value chains, focusing on export performance and offensive interests, and using a statistical approach based on trade flows. We included not only traditional cash crops like cashew nuts, cocoa, coffee, cotton, sugar, and tea, but also recently well-performing value chains like citrus, grapes, legumes and pulses, sesame seeds, and tomatoes. We found that Africa has a significant revealed comparative advantage in sesame seeds and in legumes and pulses, a steady comparative advantage for cashew nuts, cocoa, cotton, tea, and grapes, and a declining advantage for coffee. We also noticed regional differences, with the Common Market for Eastern and Southern Africa (COMESA) specialized in agriculture, unlike the Arab Maghreb Union (AMU) and Economic Community of Central African States (ECCAS). With a market share decomposition analysis, we also noticed the capacity of many African economies to change their product specialization and increase their export share in pro-growth products. The cases of Madagascar and Comoros with spices and vanilla, of Niger with sesame seeds, and of the Central African Republic with fresh fruits illustrate this flexibility well. Last, we emphasized an important feature of African agricultural exports: African exports to non-African markets are dominated (90 percent) by primary or semiprocessed products, whereas those within the continent are balanced: half of Africa's intraregional trade is associated with processed products.

We now study the defensive trade interests of African economies regarding a few agricultural value chains. Let us take the example of the cereals sector, where Africa's trade deficit is large. Studying the lack of competitiveness of this value chain can be informative and support policy recommendations, and can be just as fruitful as analyzing a competitive sector. It is important to know, first, whether all African countries are characterized by this low competitiveness for cereals, or whether some countries on the continent reveal a comparative advantage; second, whether Africa is uncompetitive in all stages of this value chain, or whether, on the contrary, it has a comparative advantage at certain stages of production; and third, whether Africa's trade imbalance in this sector is as significant in its intraregional component as it is in its extraregional relations.

In 2018, Africa significantly imported (in net terms, i.e. accounting for exports) the three major cereals (wheat, maize, rice), amounting to almost US $\$ 25$ billion per year, as well as US $\$ 4$ billion of meat and edible offal and US $\$ 4.3$ billion of dairy products and other animal products. Its annual net imports in the sugar sector are US $\$ 4.1$ billion and in the vegetable oil sector US $\$ 8.8$ billion.

We focus here on three value chains where African economies have a defensive interest: the value chain around the three major cereals (wheat, maize, rice) and cassava, the sugar value chain, and the vegetable oils value chain. Two reasons explain this focus. First, the weight of these three value chains in the total African import bill is considerable. Figure 4.1 illustrates Africa's net exports exports minus imports - in these three value chains over the 2003-2018 period. ${ }^{2}$

\footnotetext{
1 From an agronomic point of view, cassava is not a cereal; it is a root. However, cassava is used to produce close substitutes to cereals: starch, flour, animal feed, and human food preparations like bread, cakes, and cookies, and so we include it with these products.

2 As explained in Chapter 1 of this report, the lack of accuracy of African trade data is glaring (see for example Mitaritonna and Traoré 2017) This is why we have made a major effort in the statistical treatment of trade data from the United Nations COMTRADE database. This statistical treatment is explained in the annex to this report. In addition, the Chapter 5 discusses informal cross-border trade in Africa.
} 
Figure 4.1 African net exports, value chains of main cereals and cassava, vegetable oils, and sugar, 2003-2018

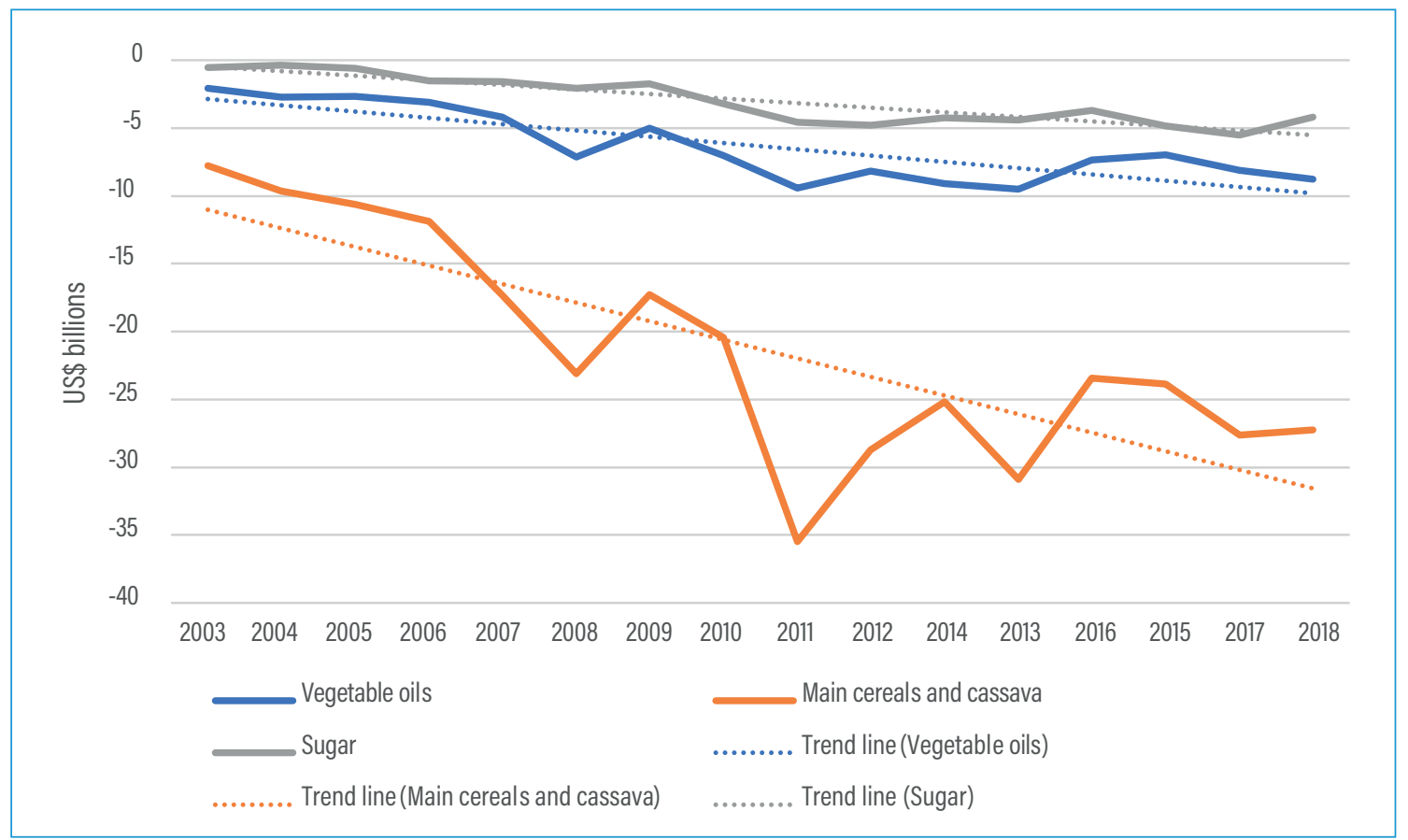

Source: 2020 AATM database.

Note: Main cereals and cassava include the entire cassava/maize/rice/wheat commodities; Vegetable oils include groundnuts/palm/rapeseeds/soy oils; in each of the three value chains, we include unprocessed, semi-processed, and processed commodities. For each series, the linear trend line has been added.

Second, these three value chains are major foods in terms of $\mathrm{kCal} /$ person/day: in four populous African countries (Egypt, Ethiopia, Nigeria, and South Africa), they represent between 38.4 percent and 71.8 percent of the total food supply in $\mathrm{kCal} /$ person/day (see Table 4.1). ${ }^{3}$

Table 4.1 Food supply by value chain, in primary crop equivalent (kCal/person/day)

\begin{tabular}{lcccc}
\hline & Egypt & Ethiopia & Nigeria & South Africa \\
\hline Cereals and cassava & 2,188 & 704 & 987 & 1,519 \\
Vegetable oils & 74 & 56 & 177 & 137 \\
Sugar & 268 & 59 & 99 & 319 \\
Total & 2,530 & 819 & 1,263 & 1,975 \\
\hline Daily per capita caloric supply & 3,522 & 2,131 & 2,700 & 3,022 \\
\hline Share of the 3 value chains & $71.8 \%$ & $38.4 \%$ & $46.8 \%$ & $65.4 \%$ \\
\hline
\end{tabular}

Source: FAOSTAT and Our World in Data (https://ourworldindata.org/food-supply), accessed May 27, 2020.

From 2003 to 2018, the African continent has been continuously in deficit in these three value chains, reaching US $\$ 40$ billion in 2018 , up from US $\$ 10$ billion in 2003. This represents a huge bill to pay in macroeconomic terms, and this deficit has quadrupled in 15 years. However, it is worth noting that first, net exports are here expressed in current US dollars, so the total reflects variation

3 The remaining value chains with African defensive interests will be studied next year: meat and edible offal, with poultry and beef, dairy products, and other animal products. 
in world prices and in exchange rates. World prices have been increasing over the period. For example, the FAO cereals price index, based on world prices of wheat, maize, and rice was 65 percent higher at the end of 2019 than in 2002-2004. ${ }^{4}$ The global price of sugar, calculated monthly by the Federal Reserve Bank of Saint Louis, is 69 percent higher at the end of 2019 than in early $2003 .{ }^{5}$ These rising world prices explain a significant part of the increasing deficit in nominal terms. In effective and nominal terms, the US dollar exchange rate is approximatively at the same level as early $2003 .{ }^{6}$

Second, over the 2003-2018 period, economic growth and population growth have been stronger in Africa than in the rest of the world. ${ }^{7}$ This implies a stronger demand for food staples imports in Africa. Third, part of this imports bill is paid with African exports of traditional cash crops and new comparative advantages as mentioned earlier.

These increasing sectoral trade deficits are a source of concern for African governments. Of course, Africa's growing external deficit in agriculture and food is a sign of rapid domestic demand growth resulting from higher economic growth, demographic pressure, and increased urbanization. But the growth of this deficit is a missed opportunity for Africa: not only is African agriculture missing out on growing markets, but also the high level of imports is exposing the continent to additional risks, as agricultural markets usually experience relatively high volatility (Conway et al. 2019).

In this chapter, we will provide more detailed statistics concerning the (un)competitiveness of African economies in these three value chains. We first study African trade patterns (trade flows and prices) in the cereals, sugar, and vegetable oils value chains using statistics for both the continent and by country, by stage of processing, and by the destination of exports and source of imports. Then we present agricultural and trade policies adopted by rich, emerging, and African countries in these three value chains. We do not make any study here of causality between these policies and the trade performance of African agriculture. We just provide facts as they are revealed by data on trade flows and policies in order to analyze to the competitiveness of these value chains.

\section{(Un)Competitiveness of three African agricultural value chains}

Competitiveness is a concept that is difficult to define but commonly used in the public debate. In its narrow way, competitiveness can be understood by comparing prices of the same commodity produced in two different places, or in a broad way, at the national level by taking into account not only trade costs but also exchange rates, institutions, and other factors. It is important to keep in mind that producers can compete on price, quality, and degree of product differentiation.

Before studying each value chain (cereals, sugar, vegetable oils) in three subsections, we provide two indicators of competitiveness - revealed comparative advantage (RCA) and the ratio of unit values - for the entire value chains at the continental level over the 2003-2018 period. This provides a global perspective before studying each value chain specifically and allows us to introduce the main indicators that will be used to gauge competitiveness.

4 See the Agricultural Market Information System website, http://www.amis-outlook.org/ (accessed April 6, 2020).

5 See https://fred.stlouisfed.org/series/PSUGAISAUSDM, accessed April 6, 2020.

6 Federal Reserve of Saint Louis, https://fred.stlouisfed.org/series/NBUSBIS (accessed April 4, 2020). It shows a depreciation of the US dollar in effective terms over 2003-2008 by more than 20\%, then an appreciation since 2011.

7 From the World Development Indicators, the average rate of real GDP growth of sub-Saharan Africa is 4.4\% over the $2003-2018$ period. For the world, it is $2.9 \%$. All countries of sub-Saharan Africa have recorded growth rates over 3.3\%, except Libya for which the GDP was stable over the period. Concerning populations, see UN DESA (2019). 
We start with RCAs. Comparative advantage is a theoretical concept regarding what an economy is best at producing, relative to other things it could produce and to other economies. RCA is a bi-ratio (or a ratio of two ratios) and compares the share of one product in a country's total exports to the share of the same product in world exports. We use the RCA index defined by Balassa (1965), in which the RCA of country i for product $j$ is measured by the product's share in the country's exports in relation to its share in world trade (Equation 4.1):

$R C A_{i j}=\frac{X_{i j} /_{X i t}}{X_{w j} / X_{w t}}$

where $X_{i j}$ and $X_{w j}$ are the values of country i's exports of product $\mathrm{j}$ and world exports of product $\mathrm{j}$, and where $X_{i t}$ and $X_{w t}$ refer to the country's total exports and world total exports. A value of less than unity implies that the country has a revealed comparative disadvantage in the product. Similarly, if the index exceeds unity, the country is said to have a revealed comparative advantage in the product.

We note that the RCA reflects the comparative advantage of a country in the current policy environment. It may be the case that a country has a strong comparative advantage in, for example, maize production, but if export bans prevent maize from being exported, the comparative advantage in maize will not be revealed. Put differently, this indicator reveals a comparative advantage from observed trade flows, without explanation: competitiveness due to access to either technology or specific endowments, or domestic policy that gives an advantage to local producers, and so on.

RCA can be calculated at different levels of aggregation: for a specific product, for a specific processing stage of a value chain, for an entire value chain, or even for a sector of an economy. It can be assessed for a country, or for a group of countries such as a regional economic community (REC), or for an entire continent.

Figure 4.2 illustrates the evolution of the RCA for the African continent in the three value chains over the 2003-2018 period. Throughout this period, the cereals and vegetable oils value chains show a comparative disadvantage, especially substantial in the case of vegetable oils, but the sugar value chain exhibits a comparative advantage continuously from 2003 to 2018 . However, this African comparative advantage in sugar is declining. 
Figure 4.2 Revealed comparative advantage of Africa, value chains of cereals, vegetable oils, and sugar, 2003-2018

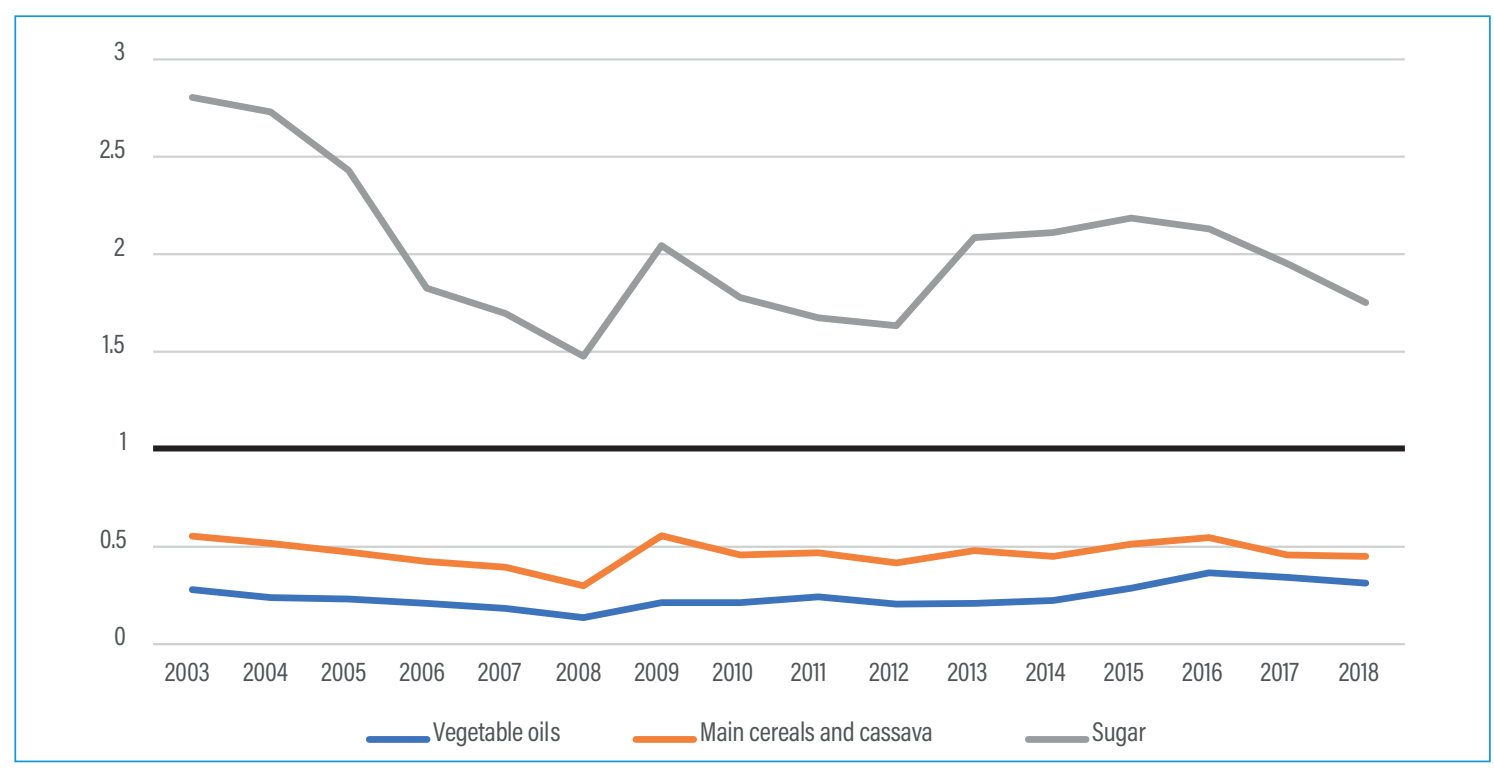

Source: 2020 AATM database.

Note: Main Cereals and Cassava include the entire cassava/maize/rice/wheat commodities; Vegetable Oils include groundnuts/palm/rapeseeds/soy oils; in each of the three value chains, we include unprocessed, semi-processed, and processed commodities. The horizontal line corresponds to an RCA of 1. An RCA greater than 1 indicates a comparative advantage; an RCA below 1 indicates no comparative advantage.

Is this figure in contradiction with Figure 4.1 and the levels of African net exports in this value chain? No. Indeed RCA (which considers only exports) and net exports (exports minus imports) measure two different economic phenomena. As we will see, concerning the sugar value chain, aside from a continental RCA which is greater than 1, national RCAs exhibit a strong dispersion and many African countries have a comparative disadvantage in this value chain. Obviously, this finding is important from the perspective of intra-African trade and has significant policy implications, in particular with respect to regional integration projects.

We confirm this perspective with an indicator of competitiveness based on price comparison. It gives, for each value chain, the ratio of unit values of exports in Africa over those in the rest of the world.

To measure competitiveness, the right method is to compare the prices of agricultural goods produced by African economies with the prices of the same goods produced by non-African economies. Unfortunately, price series for all traded goods for all world economies are not available. We also need to capture the value of traded items into a harmonized nomenclature. For this reason, we rely on the unit value of exports, which is the ratio between the value of export flows divided by the recorded quantities. These unit values are expressed in monetary units per physical units (for example, tons) when the goods from various countries are reasonably similar (for example, maize) or as an index when goods are heterogeneous.

A price difference for the same good between two countries may reflect either price competitiveness or differences in quality. We are studying agricultural goods, so the issue of quality differentiation is generally not very influential. This is especially true when we compare average unit values for homogenous products such as wheat, rice, maize, cassava, and sugarcane. However, beyond quality differentiation, higher unit values may also be associated with actual capture of preferential rents by exporters, for goods sold on the market with high tariffs, and preferences given to African countries. 
We built a trade database where trade flows have been harmonized. All flow values include the cost of insurance and freight (CIF). When bundles are composed for a continent or for a country and compared to the rest of the world, they are harmonized in such a way that differences between unit value averages cannot result from composition effects (that is, in differences in the weights used for aggregation) but only from differences in prices.

Figure 4.3 describes the evolution, from 2003 to 2018, of the ratios of unit values of African exports over unit values for the rest of the world in the three value chains. This ratio is multiplied by 100 . So, if this ratio is equal to 100 , the price of a bundle of African commodities in a value chain is equal to the price of the same bundle in the rest of the world. If it is greater than 100, the bundle of African commodities is less competitive; if it is less than 100, the bundle of African commodities is more competitive.

Figure 4.3 Ratio of exports unit values, Africa over Rest of the World, value chains of cereals, sugar, and vegetable oils, 2003-2018

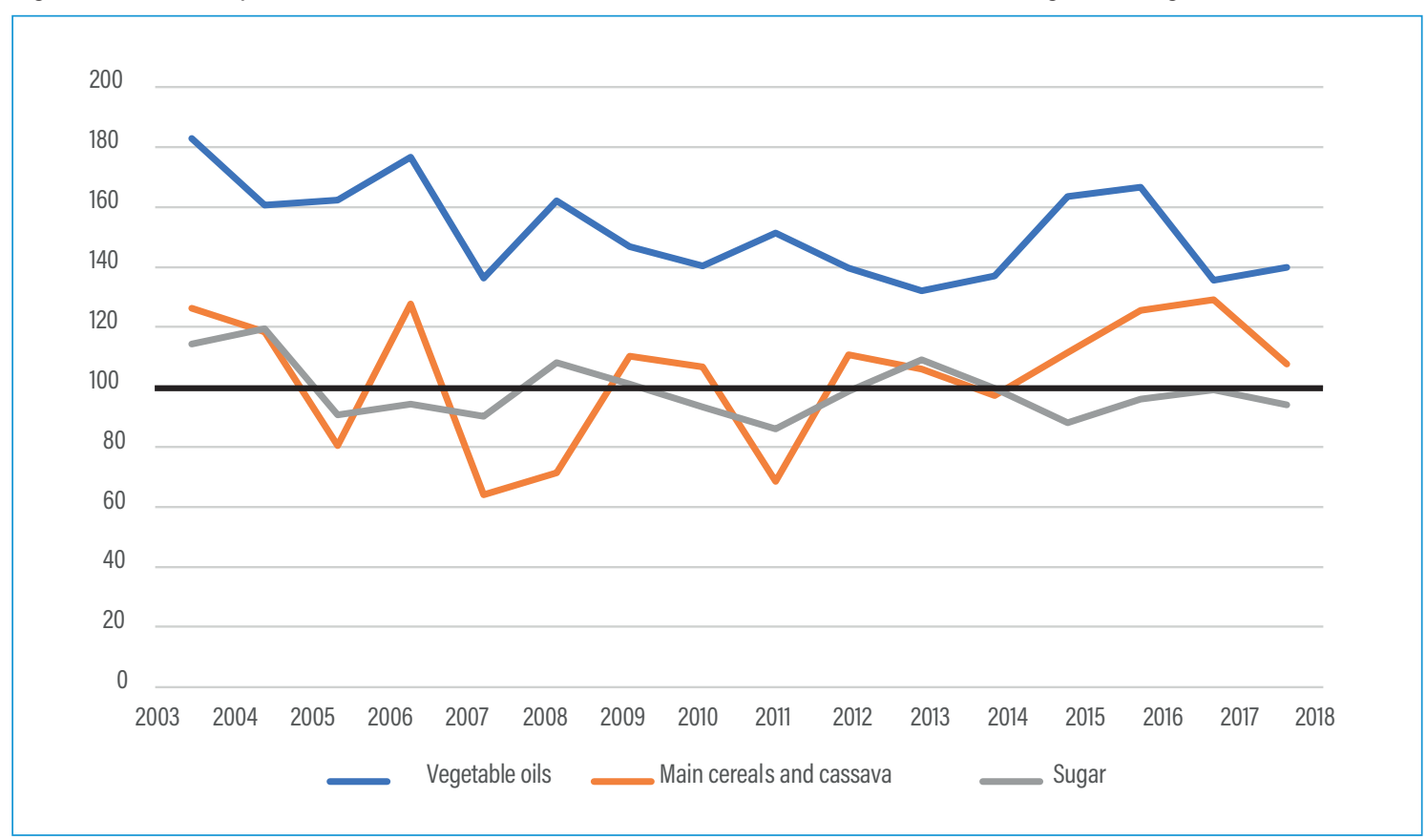

Source: 2020 AATM database.

Note: The horizontal line corresponds to an indicator of 100 and delimits the split between years when Africa's products are price-competitive (less than 100) from years when they are not (greater than 100).

From Figure 4.3, we see that globally the African vegetable oils value chain has never been competitive over the 2003-2018 period, whereas the sugar value chain has been competitive in most years since 2005 (excepting 2008, 2009, and 2013). In 2009, the average unit value of African exports in the sugar value chain was very close to that of the rest of the world's exports. Concerning the cereals value chain, export prices in Africa are more often higher than export prices in the rest of the world (over 16 years, it happens 11 times): this suggests a lack of price-competitiveness of African producers.

We now describe each value chain. 


\section{Main cereals and cassava}

The cereals value chain is represented in Figure 4.4. We identified three stages of processing in the cereals value chains (unprocessed; semi-processed; processed) and four sub-chains: maize, rice, wheat, and cassava.

Figure 4.4 Cereals value chain

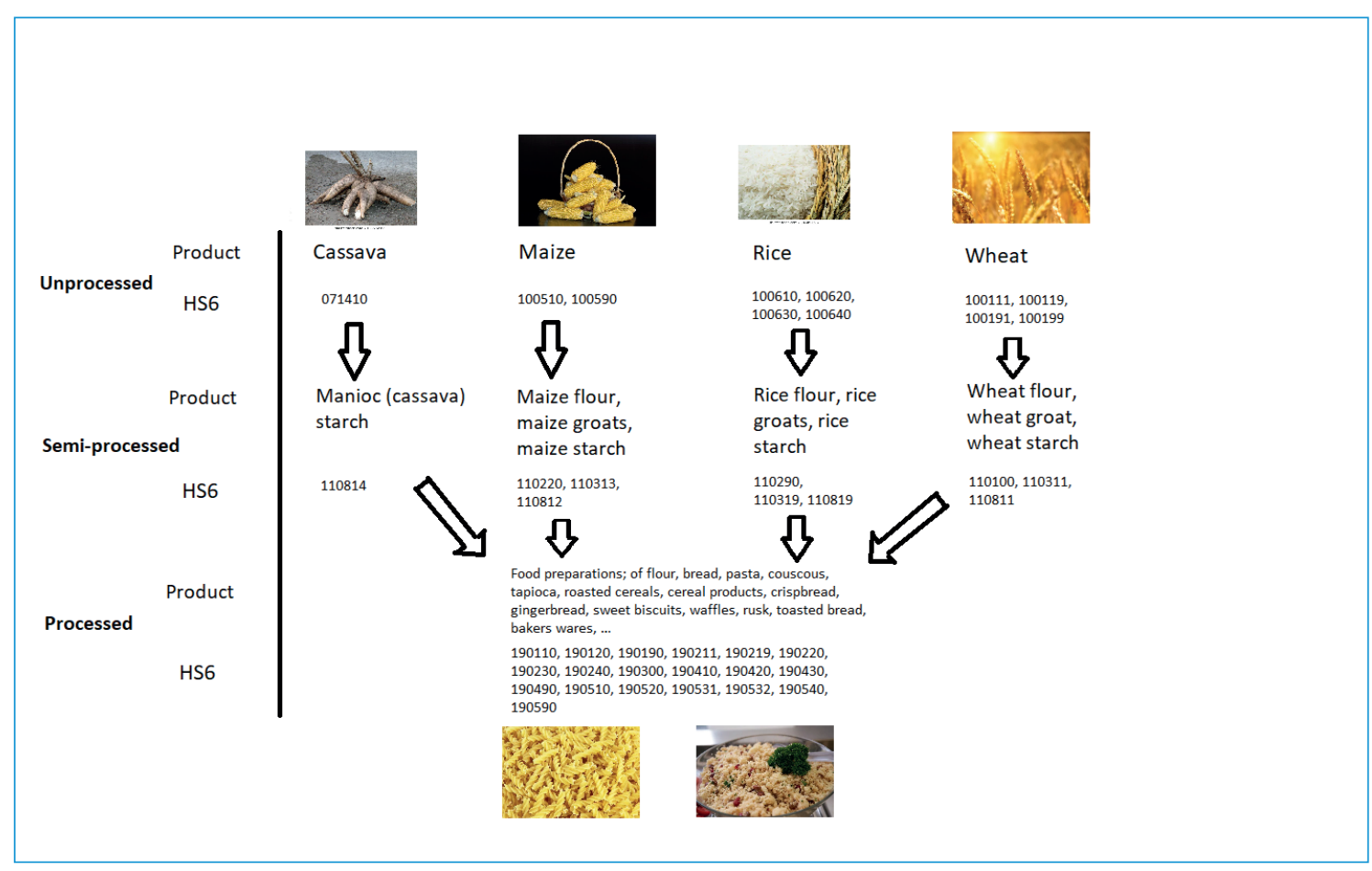

Source: Authors' own elaboration.

Note: Photos from Pixabay; numbers refer to Harmonized System 6 (HS6) codes.

Figure 4.4 includes the HS6 codes that are included at each processing stage and for each cereal. The unprocessed stage is the crops. The semi-processed stage consists of flour, groats, and starch. The processed stage includes food preparations using these cereals: bread, pasta, couscous, tapioca, cereal products, biscuits, waffles, and so on. As it is not possible to distinguish among food preparations based on cassava, maize, rice, and wheat, the processed stage is the same for each cereal.

Who are the big players in this value chain? Table 4.2 points out the 10 largest producers of cassava, maize, rice, and wheat in 2018. While a few African countries are among the largest producers of cassava, especially Nigeria, Democratic Republic of the Congo, and Ghana, the world market of this crop is significantly smaller than those of maize, rice, and wheat. For those three cereals, there is no African country among the 10 largest producers. China, India, Ukraine, and the United States are often among the largest producers. 
Table 4.2 Production in volume of cassava, maize, rice, and wheat, 10 largest producers, 2018

\begin{tabular}{|c|c|c|c|c|c|c|c|}
\hline \multicolumn{2}{|l|}{ Cassava } & \multicolumn{2}{|l|}{ Maize } & \multicolumn{2}{|l|}{ Rice } & \multicolumn{2}{|l|}{ Wheat } \\
\hline Country & Production (MT) & Country & Production (MT) & Country & Production (MT) & Country & Production (MT) \\
\hline 1. Nigeria & $59,475,202$ & 1. USA & $392,450,840$ & 1. China & $214,078,796$ & 1. China & $131,447,224$ \\
\hline 2. Thailand & $31,678,017$ & 2. China & $257,173,900$ & 2. India & $172,580,000$ & 2. India & $99,700,000$ \\
\hline 3. DR Congo & $29,952,479$ & 3. Brazil & $82,288,298$ & 3. Indonesia & $83,037,000$ & 3. Russia & $72,136,149$ \\
\hline 4. Ghana & $20,845,960$ & 4. Argentina & $43,462,323$ & 4.Bangladesh & $56,417,319$ & 4. USA & $51,286,540$ \\
\hline 5. Brazil & $17,644,733$ & 5. Ukraine & $35,801,050$ & 5. Viet Nam & $44,046,250$ & 5. France & $35,798,234$ \\
\hline 6. Indonesia & $16,119,020$ & 6. Indonesia & $30,253,938$ & 6. Thailand & $32,192,087$ & 6. Canada & $31,769,200$ \\
\hline 7. Viet Nam & $9,847,074$ & 7. India & $27,820,000$ & 7. Myanmar & $25,418,142$ & 7. Pakistan & $25,076,149$ \\
\hline 8. Angola & $8,659,552$ & 8. Mexico & $27,169,977$ & 8. Philippines & $19,066,094$ & 8. Ukraine & $24,652,840$ \\
\hline 9. Mozambique & $8,525,451$ & 9. Romania & $18,663,939$ & 9. Brazil & $11,749,192$ & 9. Australia & $20,941,134$ \\
\hline 10. Cambodia & $7,646,022$ & 10. Canada & $13,884,800$ & 10. Pakistan & $10,802,949$ & 10. Germany & $20,263,500$ \\
\hline
\end{tabular}

Source: FAOSTAT.

Note: MT = metric tons; DR Congo $=$ Democratic Republic of the Congo

Figure 4.5 illustrates the RCAs of African countries in the cereals value chain based on the 20162017-2018 average trade flows. Of the 52 African countries for which we have trade statistics, only 12 have a revealed comparative advantage in the cereals value chain. This revealed advantage is strongest for Niger, Uganda, Sierra Leone, Burundi, Rwanda, Tanzania, Gambia, and Senegal (RCA greater than 2). 
Figure 4.5 Revealed comparative advantage by African country, main cereals and cassava value chain, average 2016-2017-2018

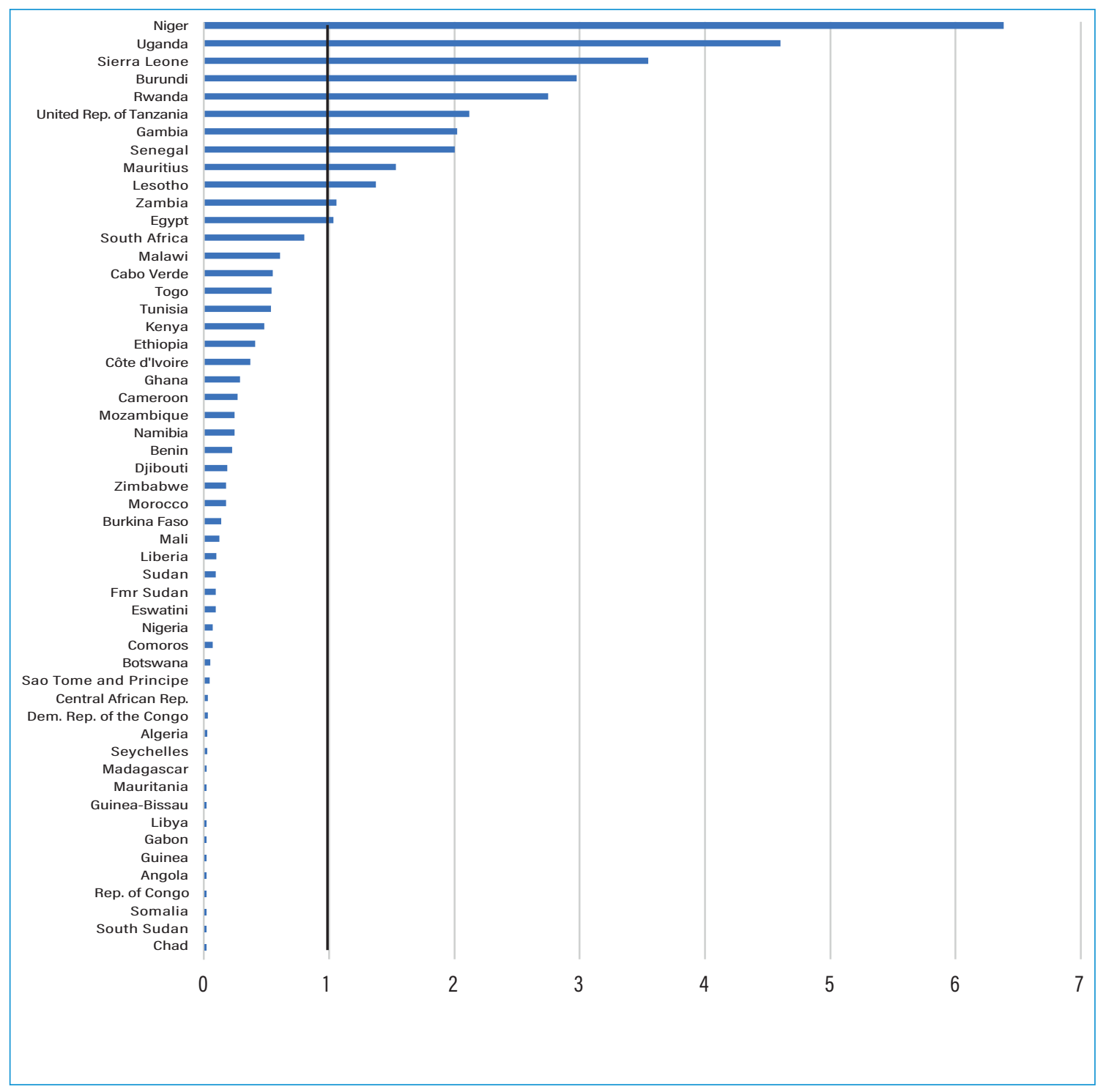

Source: 2020 AATM database.

Note: Main Cereals include the entire cassava/maize/rice/wheat commodities; we include unprocessed, semi-processed, and processed commodities. The vertical line corresponds to an RCA of 1 and delimits the split between countries with a comparative advantage (RCA greater than 1 ) and countries without a comparative advantage (RCA less than 1 ) in the sugar value chain.

Even if a significant share of total exports of a country is from the cereals value chain, the country may also import large quantities of commodities within the same value chain. This trade pattern may reflect exports and imports in different processing stages, trade in differentiated products, and/or trade flows initiated in different regions of the country. We complement country-level RCAs in the cereals value chain with country-level net exports (Figure 4.6). The three largest net importing countries are Egypt, Algeria, and Nigeria. 
Figure 4.6 Net exports by African country and by stage of processing, main cereals and cassava value chains, average 20162018

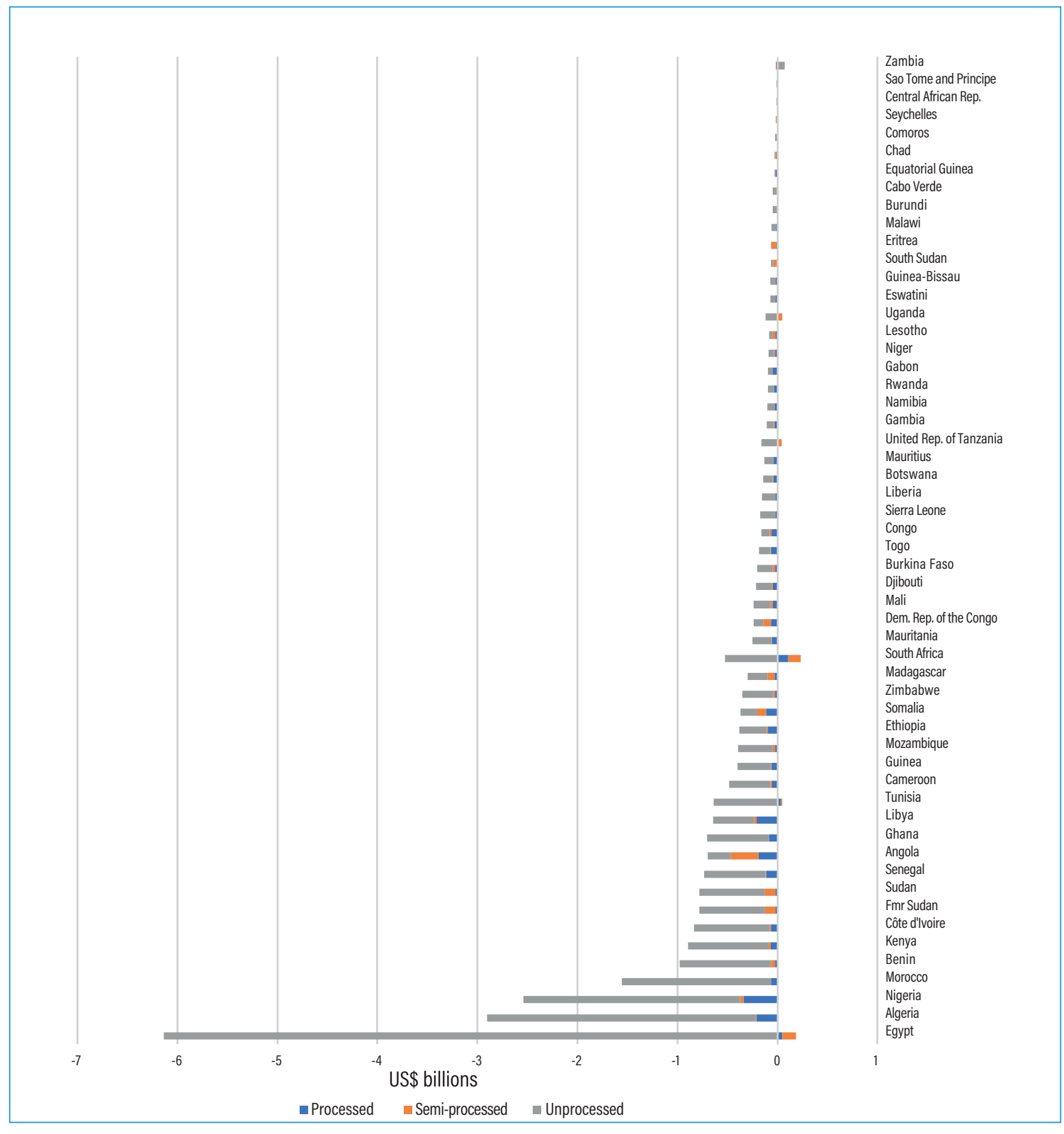

Source: 2020 AATM database.

Note: Main Cereals and Cassava include the entire cassava/maize/rice/wheat commodities.

Figure 4.6 also shows the decomposition by processing stages. A major share of trade in this value chain consists of unprocessed commodities (crops). On average from 2016 to 2018, Egypt and South Africa imported US $\$ 6.1$ billion and US $\$ 524$ million, respectively, of unprocessed crops in the value chain while exporting US $\$ 184$ million and US\$229 million, respectively, of semi-processed and processed products in the same value chain. Indeed, the large African deficit in this value chain mostly consists of a deficit in unprocessed commodities. ${ }^{8}$ 
Most of the deficit of African countries in unprocessed cereals occurs in wheat, which accounts for more than 60 percent of the continental trade deficit in this value chain (Figure 4.7) over the period, while the trade deficit in rice accounts for 24 percent. $^{9}$ The surplus in cassava is tiny. A few African countries are net exporters of (unprocessed) wheat, in significant quantities for South Africa (average surplus of US\$176 million over 2016-2018), Zambia (US\$90 million), and Uganda (US\$75 million), more moderately for Burkina Faso (US\$4 million) and Sudan (US\$1 million). Tanzania has a small surplus in (unprocessed) cassava over the same period (US $\$ 5$ million).

Figure 4.7 Net exports of Africa by type of crops, main cereals and cassava value chain, unprocessed stage, 2003-2018

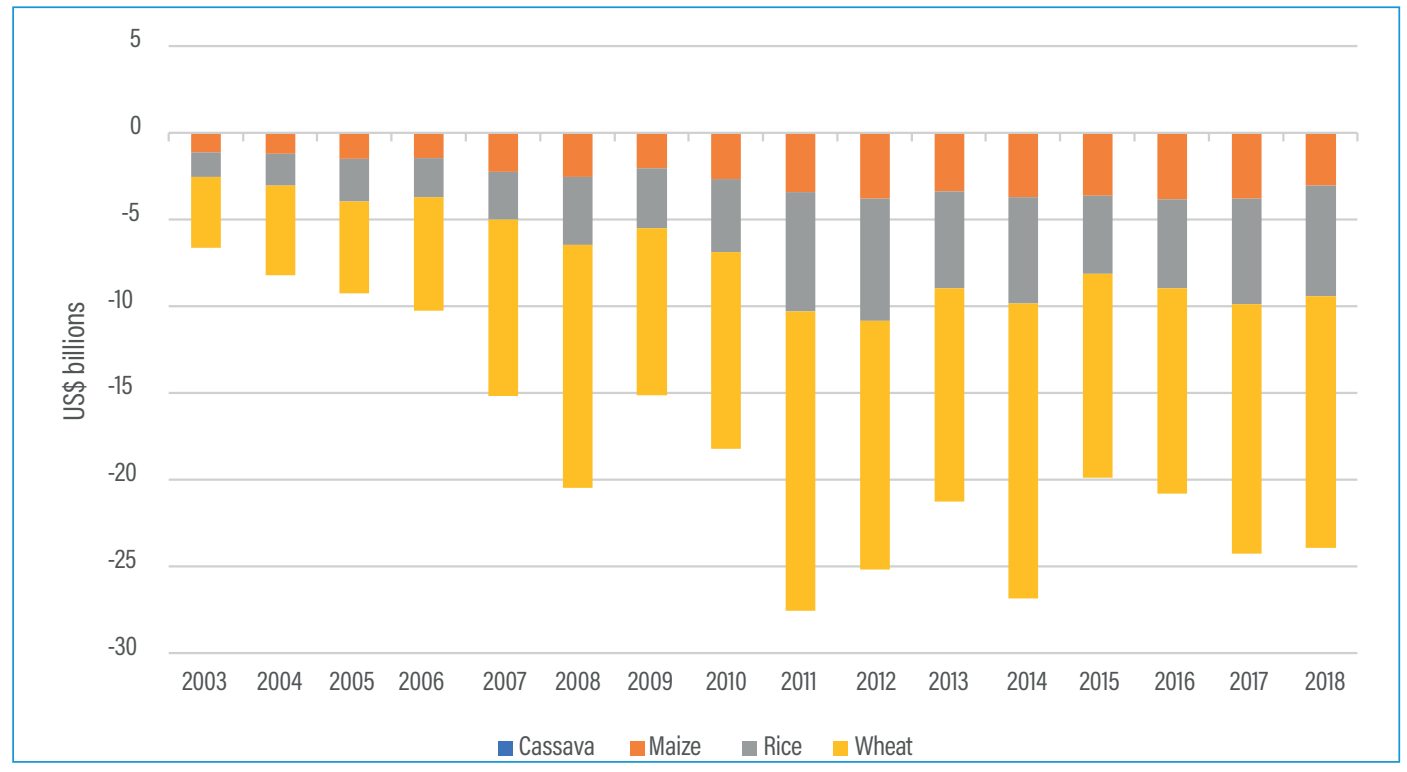

Source: 2020 AATM database.

Note: Net exports of cassava are not visible as they are tiny; they are positive for a total of US $\$ 3$ million in 2018 , around -0.1 percent of total sold.

Figure 4.8 provides the RCAs for Africa by processing stage over the 2003-2018 period. It shows that although Africa has a comparative disadvantage in the unprocessed and processed stages, it has a comparative advantage in the semi-processed stage of the cereals value chain (flour, groats, starch) and this advantage has been increasing since 2008. As will be shown later, this is largely because, most of the semi-processed cereals are chiefly exported to other African countries where tariff escalation is less pronounced than in OECD countries. RCA by country at the semi-processed stage is especially large in Sierra Leone, Burundi, Uganda, Lesotho, Rwanda, Tanzania, and Egypt (decreasing order). 
Figure 4.8 Revealed comparative advantage of Africa by processing stage, main cereals and cassava value chain, 2003-2018

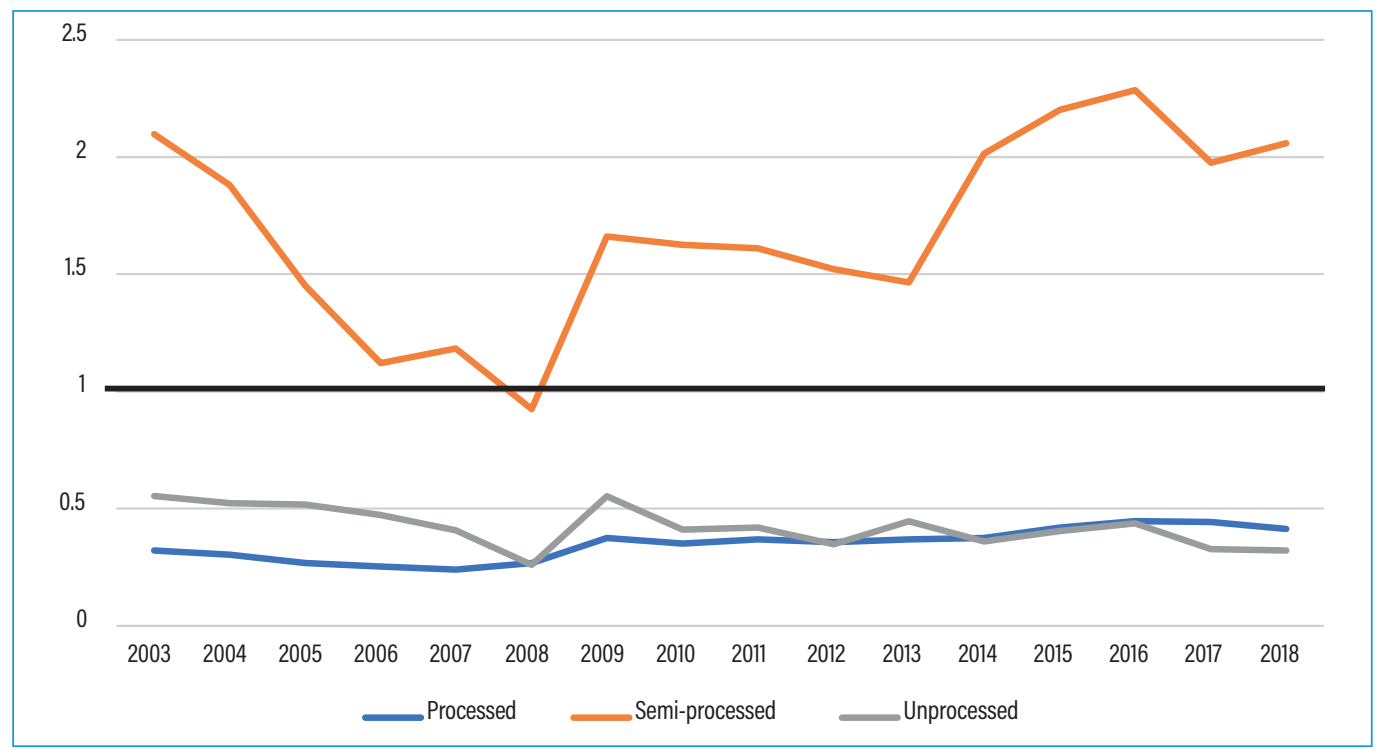

Source: 2020 AATM database.

Note: Main Cereals and Cassava include the entire cassava/maize/rice/wheat commodities. The horizontal line corresponds to an RCA of 1 . An RCA greater than 1 indicates a comparative advantage; an RCA below 1 indicates no comparative advantage.

As mentioned earlier, in the cereals value chain, a comparison of average unit values of exports in Africa with this statistic for the rest of the world reveals that prices are higher in Africa, which means a lack of price-competitiveness. If we look at the ratio of unit values of exports in the main cereals and cassava value chain in each African country over unit values of the same bundle in the rest of the world, we see that only a few African countries are price-competitive: Benin, Burkina Faso, Republic of Congo, Côte d'Ivoire, Libya, Madagascar, Mozambique, Seychelles, Sudan, Togo, and Uganda.

Looking at these ratios by processing stage, Figure 4.9 shows that the export prices of unprocessed cereals are higher in Africa than in the rest of the world, except for specific years, notably 2007, 2008, and 2011, when world markets were volatile. Differences in prices can be large, reaching 54 percent in 2016. Prices of African exports of semi-processed cereal products are closer to world prices. For African processed cereal products, their relatively low unit values may reflect differences in quality (vertical product differentiation). 
Figure 4.9 Ratio of unit values of exports, Africa over Rest of the World by processing stage, main cereals and cassava value chain, 2003-2018

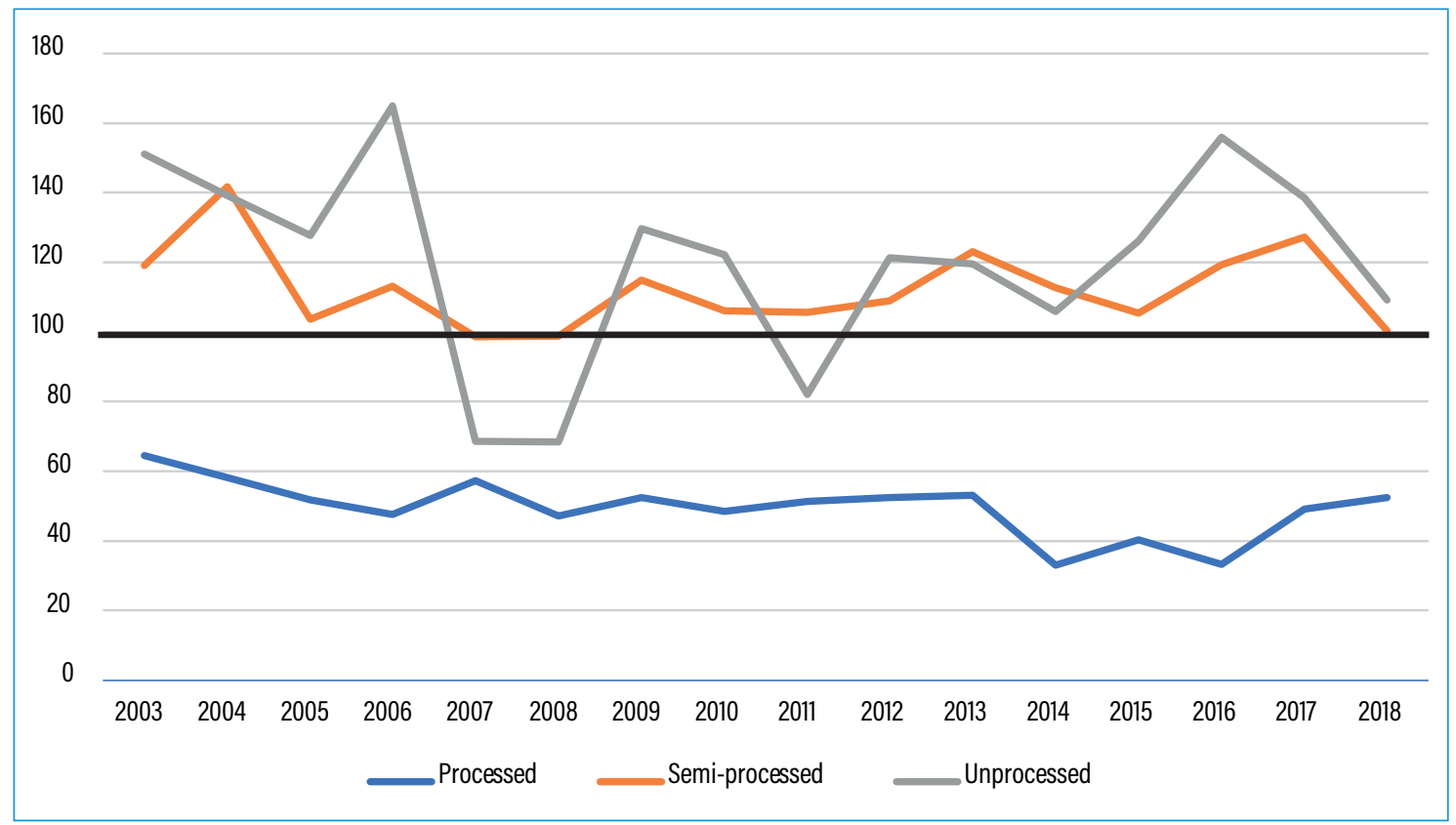

Source: 2020 AATM database.

Note: Main Cereals and Cassava include the entire cassava/maize/rice/wheat commodities. The horizontal line corresponds to an indicator of 100 and delimits the split between years when Africa's products are price-competitive (less than 100) and years when they are not (greater than 100).

Figure 4.10 illustrates the evolution of African exports in the main cereals and cassava value chain by processing stage and by destination (either intra- or extra-African exports) over the 2003-2018 period.

Figure 4.10 African exports by destination and by processing stage, main cereals and cassava value chain, 2003-2018

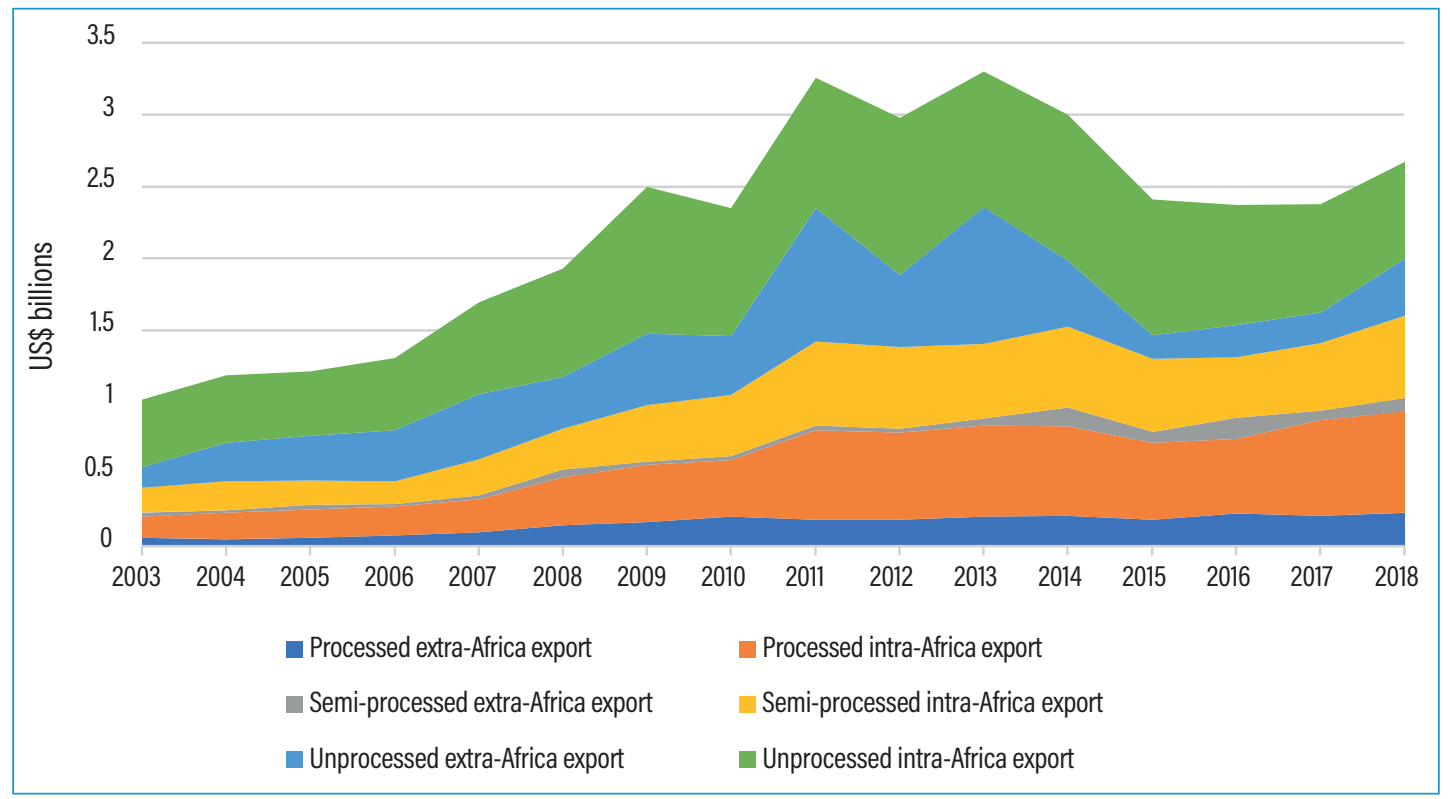

Source: 2020 AATM database.

Note: Main Cereals include the entire cassava/maize/rice/ wheat commodities. 
Exports of processed and semi-processed products are mainly intra-African exports. While the bulk of unprocessed exports are also intra-African, unprocessed extra-African are sometimes significant: in 2011 and 2013, extra-African exports of unprocessed cereals were slightly larger than intra-African exports. Extreme climatic events occurred between 2011 and 2013, including severe droughts in Argentina, Russia, and the United States, intense rain damage in Australia, and even a freeze in Mexico that hurt part of the local standing corn crop. This led to extremely volatile world prices for cereals and an upheaval in the geographical pattern of world trade in cereals.

Figure 4.11 shows African imports (in current US dollars) in the main cereals and cassava value chain. The striking feature of the structure of African imports in this value chain is the overwhelming weight of unprocessed products from the rest of the world: more than 80 percent of the total in 2016, 2017, and 2018. Also noteworthy is the relative importance of imports, again from the rest of the world, of processed products.

Figure 4.11 African imports by origin and by processing stage, main cereals and cassava value chain, 2003-2018

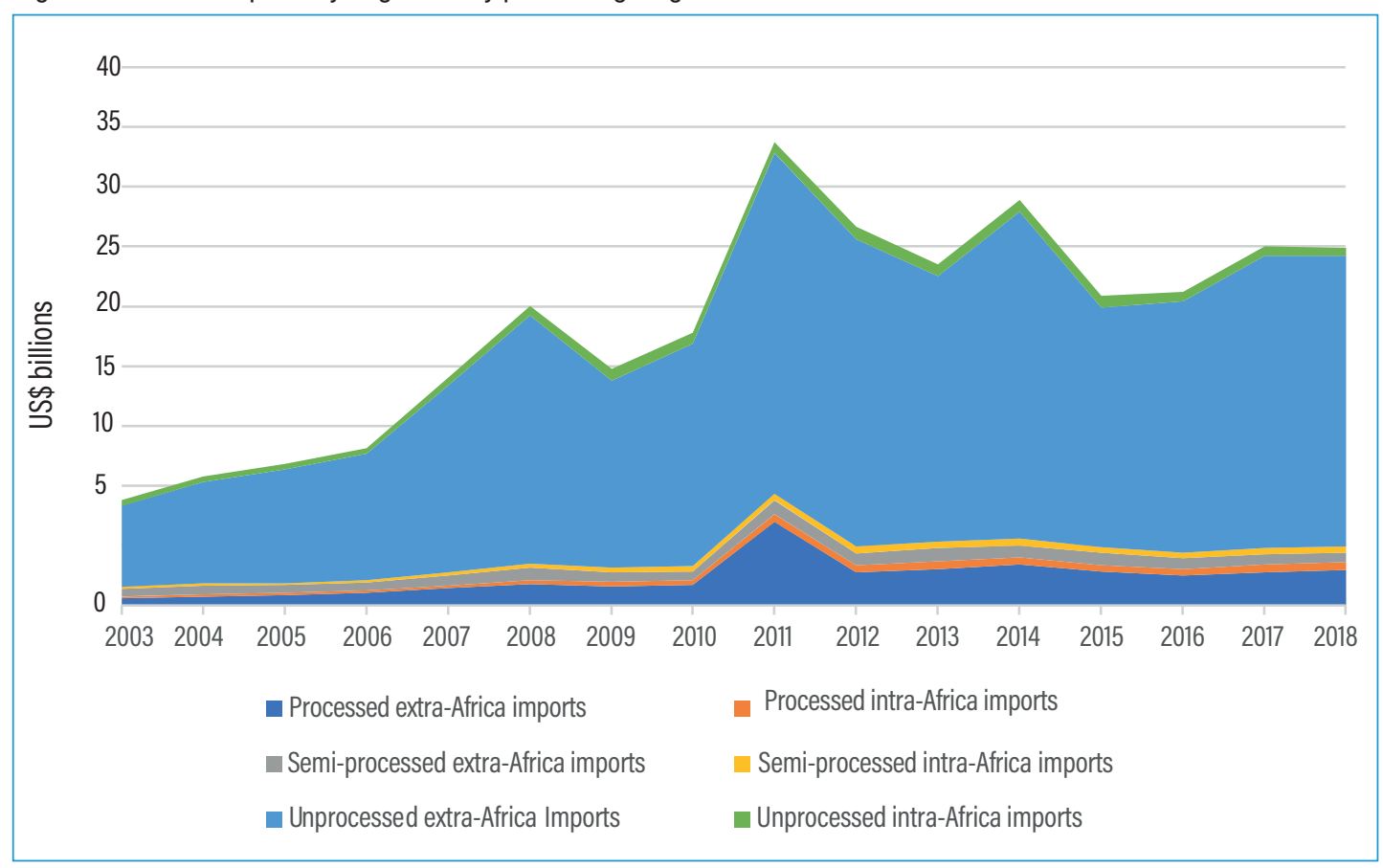

Source: 2020 AATM database.

Note: Cereals include the entire cassava/maize/rice and wheat commodities.

\section{Sugar}

Figure 4.12 depicts the sugar value chain. Both sugar beet and sugarcane are produced in Africa. These two crops are used in the semi-processed stage to produce sugar and molasses. In the same way as the cereal value chain, there is a single stage of processed products for these crops: sucrose and sugar confectionery. 
Figure 4.12 Sugar value chain

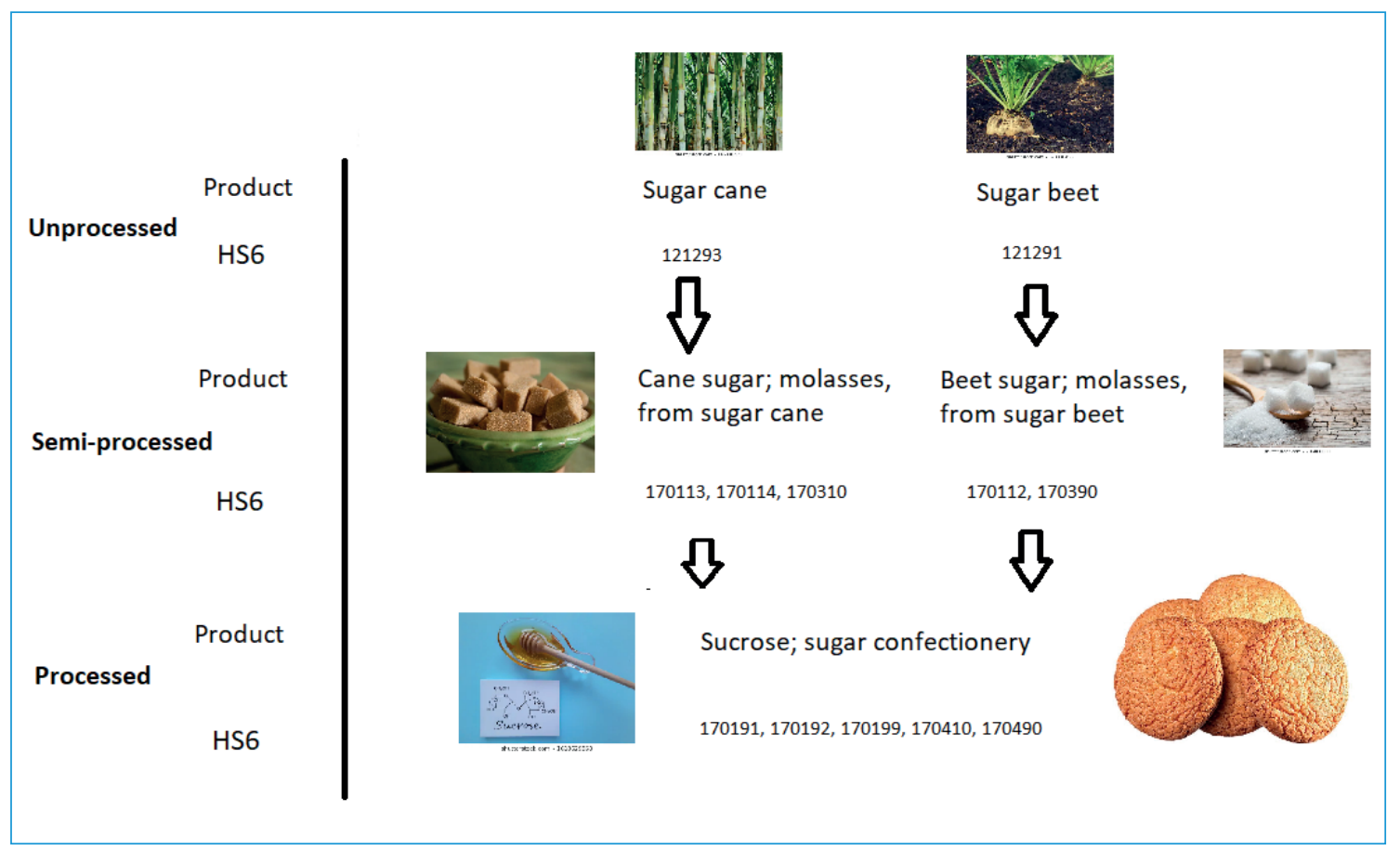

Source: Authors' elaboration.

Note: Photos from Pixabay; numbers refer to Harmonized System 6 (HS6) codes.

Table 4.3 lists the 10 largest producers of sugar beet and sugarcane in 2018. The world market for sugarcane is significantly larger than that for sugar beet. There is no African country in this list, except Egypt for sugar beet (9th); for sugarcane South Africa is 14th.

Table 4.3 Production of sugarcane and sugar beet in volume, 10 largest producers, 2018

\begin{tabular}{|l|r|l|r|}
\hline \multicolumn{2}{|c|}{ Sugar beet } & \multicolumn{2}{c|}{ Sugarcane } \\
\hline Country & Production (MT) & Country & Production (MT) \\
\hline 1. Russia & $42,065,957$ & 1. Brazil & $746,828,157$ \\
2. France & $39,579,925$ & 2. India & $376,900,000$ \\
3. USA & $30,068,647$ & 3. China & $108,718,971$ \\
4. Germany & $26,191,400$ & 4. Thailand & $104,360,867$ \\
5. Turkey & $18,900,000$ & 5. Pakistan & $67,173,975$ \\
6. Poland & $14,302,911$ & 6. Mexico & $56,841,523$ \\
7. Ukraine & $13,967,700$ & 7. Colombia & $36,276,860$ \\
8. China & $12,077,618$ & 8. Guatemala & $35,568,207$ \\
9. Egypt & $11,222,720$ & 9. Australia & $33,506,830$ \\
10. UK & $7,620,000$ & 10. USA & $31,335,984$ \\
\hline
\end{tabular}

Source: FAOSTAT.

Note: $\mathrm{MT}=$ Metric tons

In the introduction of this section, Figure 4.2 showed a comparative advantage of the African continent in the entire value chain. The calculation of RCAs at the country level (Figure 4.13), on average over 2016-2018 for the entire value chain, shows that this comparative advantage is large 
in six countries. Eswatini and Mauritius have the largest RCAs with 80.9 and 42.8, respectively. They have been dropped out of Figure 4.13 as their inclusion makes the graph less readable. RCAs of Malawi, Uganda, Zimbabwe, Gambia, and Mozambique (decreasing order), are greater than 5: this is still a strong comparative advantage. However, according to this indicator, 30 African countries had a comparative disadvantage in this value chain in 2016-2018.

Figure 4.13 Revealed comparative advantage by African country, sugar value chain, average 2016-2018

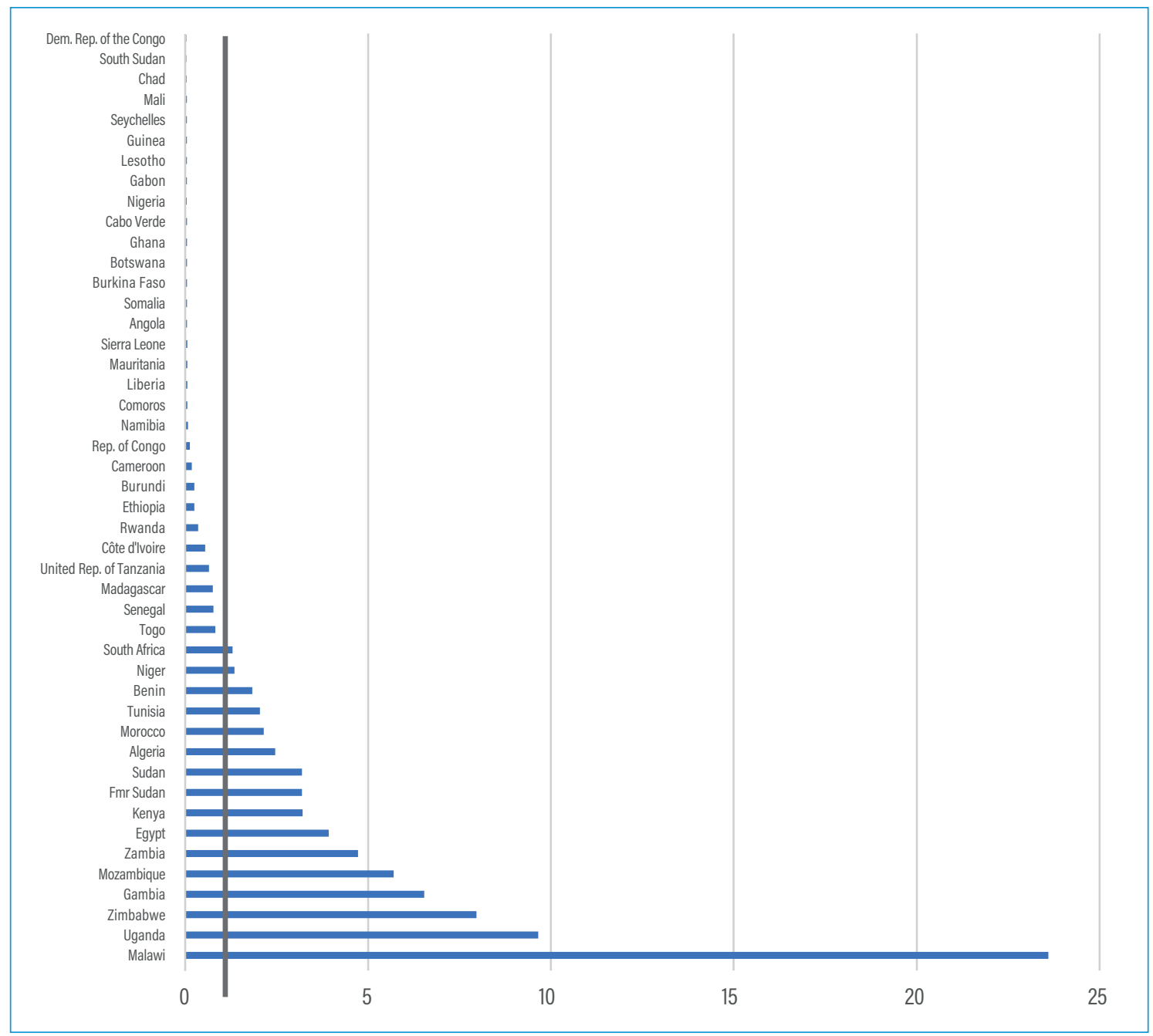

Source: 2020 AATM database.

Note: We include unprocessed, semi-processed, and processed commodities. Eswatini and Mauritius have been dropped out of the graph as their RCAs are respectively 80.9 and 42.8: their inclusion makes the graph much less readable. The vertical line corresponds to an RCA of 1 and delimits the split between countries with a comparative advantage (RCA greater than 1) and countries without a comparative advantage (RCA less than 1) in the sugar value chain.

Figure 4.14 indicates the net exports of each African country on average in 2016-2018 by processing stage. 
Figure 4.14 Net exports by African country and by processing stage, sugar value chain, average 2016-2018

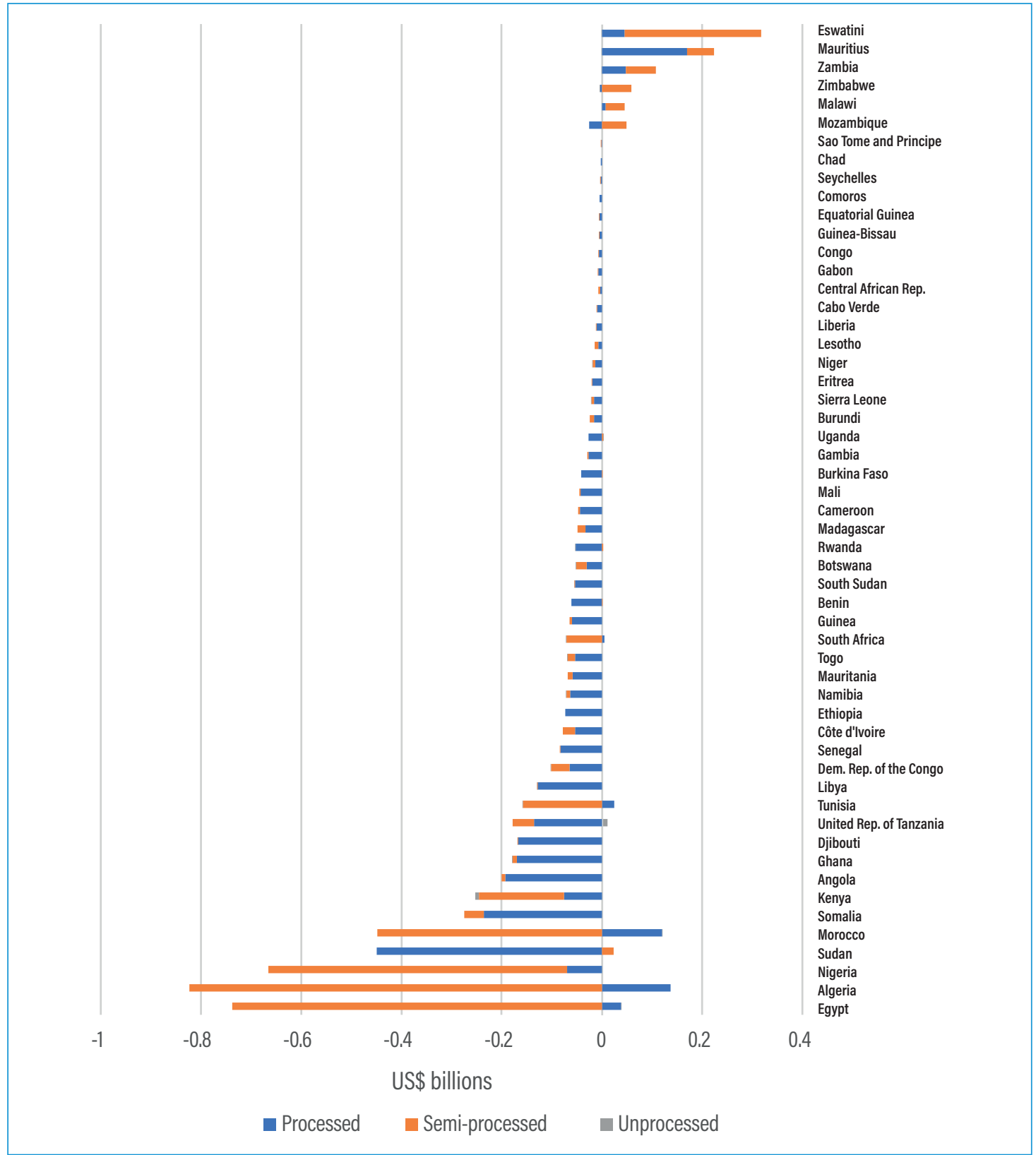

Source: 2020 AATM database.

Trade in unprocessed commodities (sugarcane and sugar beet) is tiny. Africa is a net exporter of unprocessed products in this value chain (sugarcane), but these net exports represented less than 0.1 percent of total African trade in this value chain over 2016-2018.

The largest African importers in this value chain are Algeria, Egypt, Nigeria, Morocco, and Sudan. Patterns differ among these importing countries: Algeria, Egypt, and Morocco are net importers of semi-processed products but are net exporters of processed products (sugar confectionery). Nigeria is a net importer of both semi-processed and processed products. Sudan is a net importer of processed products, but a net exporter of semi-processed products. 
Six African countries were globally net exporters in the sugar value chain for 2016-2018: Eswatini, Mauritius, Zambia, Zimbabwe, Malawi, and Mozambique. Here again, patterns differ. Eswatini, Malawi, and Zambia are net exporters of both semi-processed and processed products, with most of these net exports in the former category. Mauritius also is a net exporter at both processing stages, but the bulk of these net exports is in the processed stage. Mozambique and Zimbabwe are net exporters of semi-processed products but net importers of processed products.

Figure 4.15 brings a positive note. It shows RCAs at the continental level by processing stage over the 2003-2018 period. Let us put aside the unprocessed stage of production where trade is not significant. The semi-processed stage of production exhibits a decreasing, then steady (since 2011) comparative advantage, while the processed stage shows an increasing comparative advantage.

Figure 4.15 Africa, revealed comparative advantage by processing stage, sugar value chain, 2003-2018

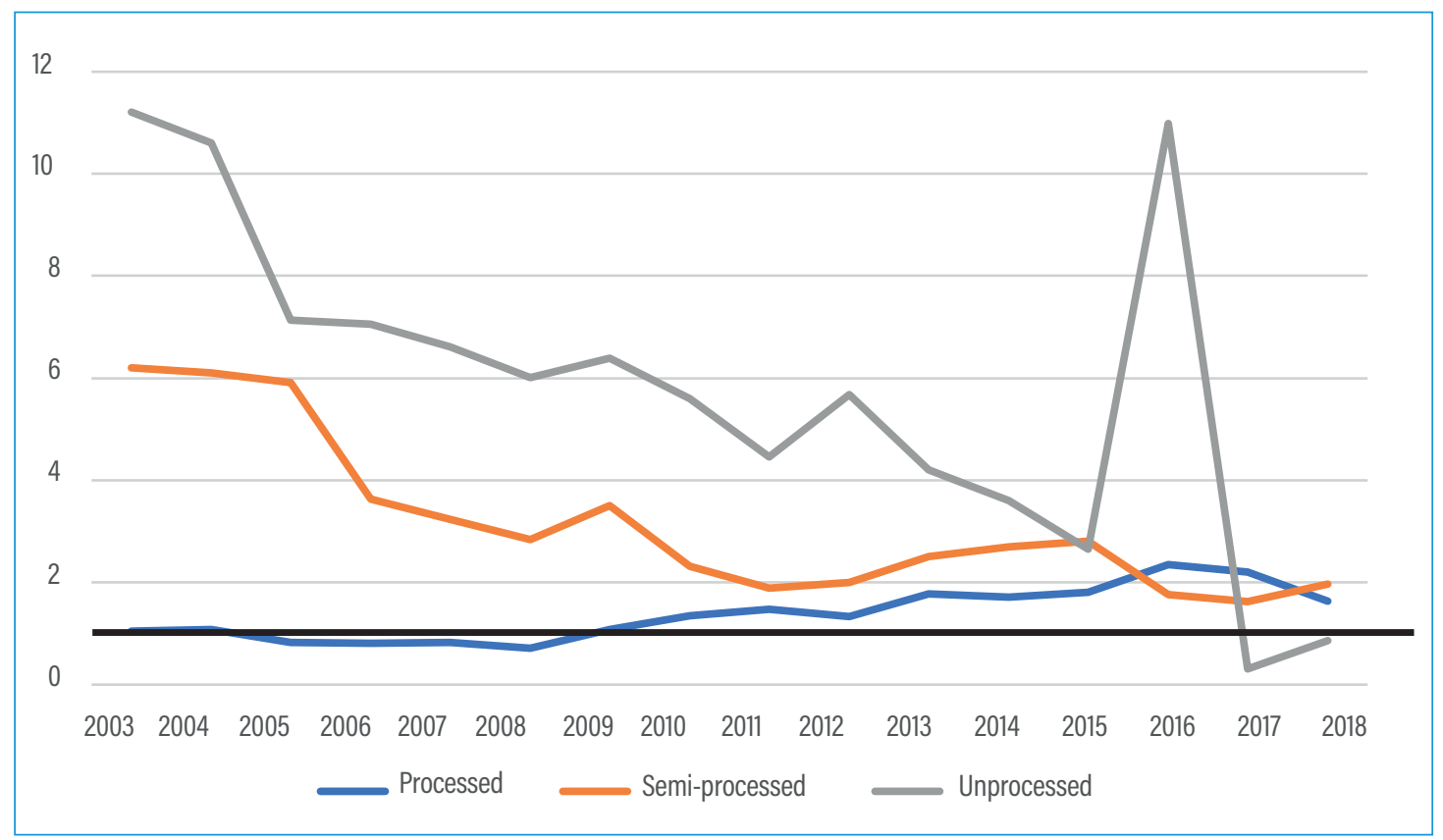

Source: 2020 AATM database.

Note: The horizontal line corresponds to an RCA of 1. An RCA greater than 1 indicates a comparative advantage; an RCA below 1 indicates no comparative advantage.

Calculations of RCAs by country and processing stage, on average for 2016-2018, show:

- At the unprocessed stage, a comparative advantage for Tanzania (very large), Egypt, Burundi, and Uganda.

- At the semi-processed stage, a large comparative advantage for Eswatini, Malawi, Mauritius, Zimbabwe, Sudan, and Mozambique; significant smaller advantage for Zambia, Benin, Uganda, Madagascar, and South Africa.

- At the processed stage, a large comparative advantage for Mauritius, Eswatini, Uganda, Malawi, and Gambia; a significant but smaller comparative advantage for Egypt, Kenya, Algeria, Zambia, Morocco, Tunisia, Mozambique, Niger, Togo, Senegal, South Africa, and Zimbabwe.

From Figure 4.3 above, we concluded that, regarding the whole sugar value chain, export prices on average, as indicated by export unit values, are lower in Africa than in the rest of the world. 
Figure 4.16 indicates the same ratio of export unit values for Africa by processing stage; note we do not include the unprocessed stage as trade in these products (crops) is tiny and unit values are volatile. At the processed stage, this ratio systematically exhibits price-competitiveness of African products. At the semi-processed stage, after a period of non-competitiveness from 2003 to 2009, export unit values of African products are close to those for the rest of the world.

Figure 4.16 Ratio of export unit values by processing stage, Africa over Rest of the World, sugar value chain, 2003-2018

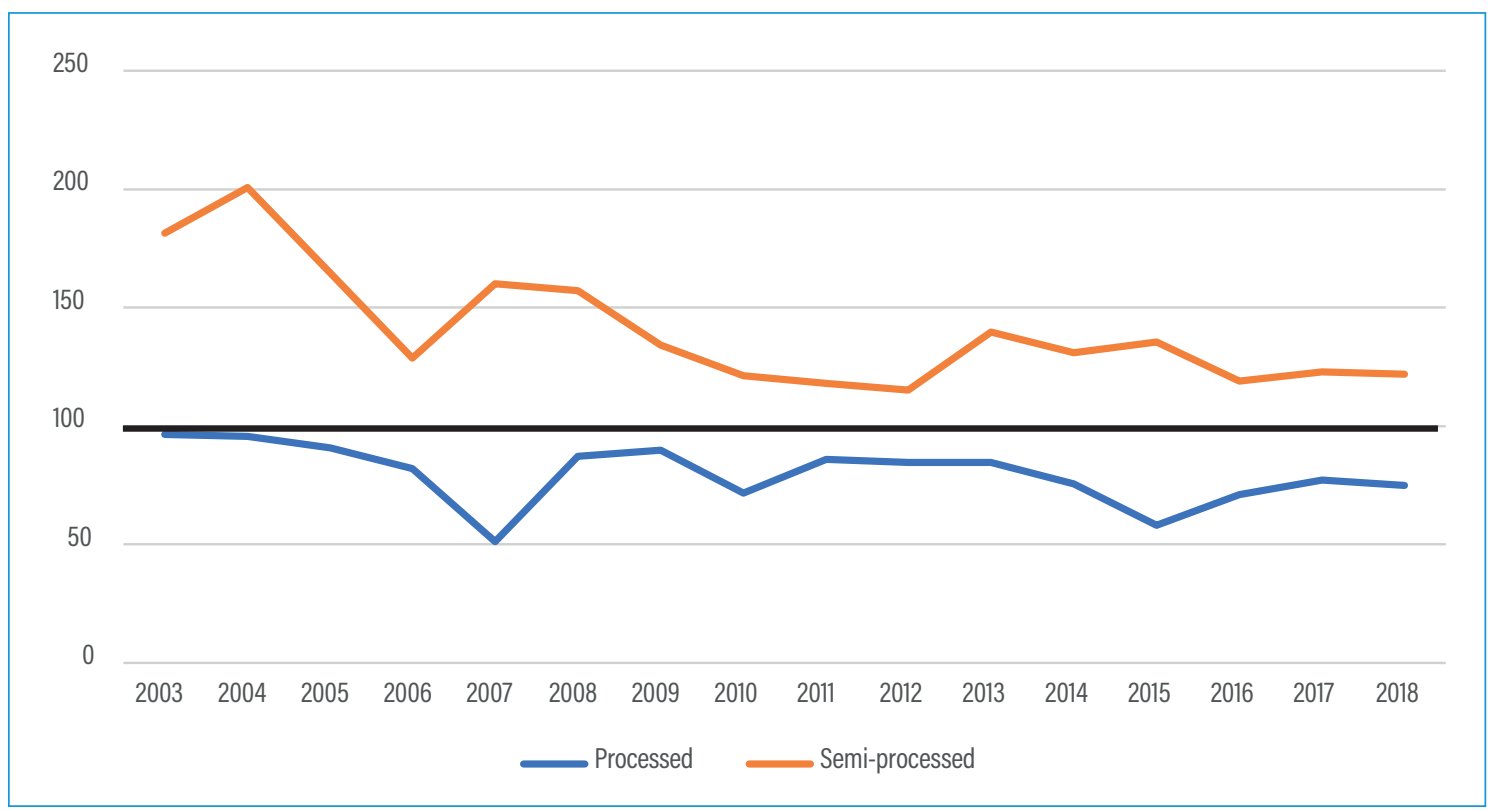

Source: 2020 AATM database.

Note: The horizontal line corresponds to an indicator of 100 and delimits the split between years when Africa's products are price-competitive (less than 100) and years when they are not (greater than 100).

Figure 4.17 shows the distribution of African exports in the sugar value chain by processing stage and by destination (intra-Africa vs. extra-Africa) over the 2003-2018 period. Exports of unprocessed products are close to zero. While between 2003 and 2008, the bulk of African exports was extraAfrica semi-processed exports, over the recent period, these exports are distributed relatively equally among the four remaining categories. The growth of African exports of processed sugar products (both extra- and intra-Africa) is worth noting, from 24 percent in 2003 to more than 60 percent in 2018, with an increasing importance of intra-African exports of processed products, which is now the leading category. The share of intra-African exports in the sugar value chain has increased from 40 percent to 60 percent of total exports. 
Figure 4.17 African exports by processing stage and by destination, sugar value chain, 2003-2018

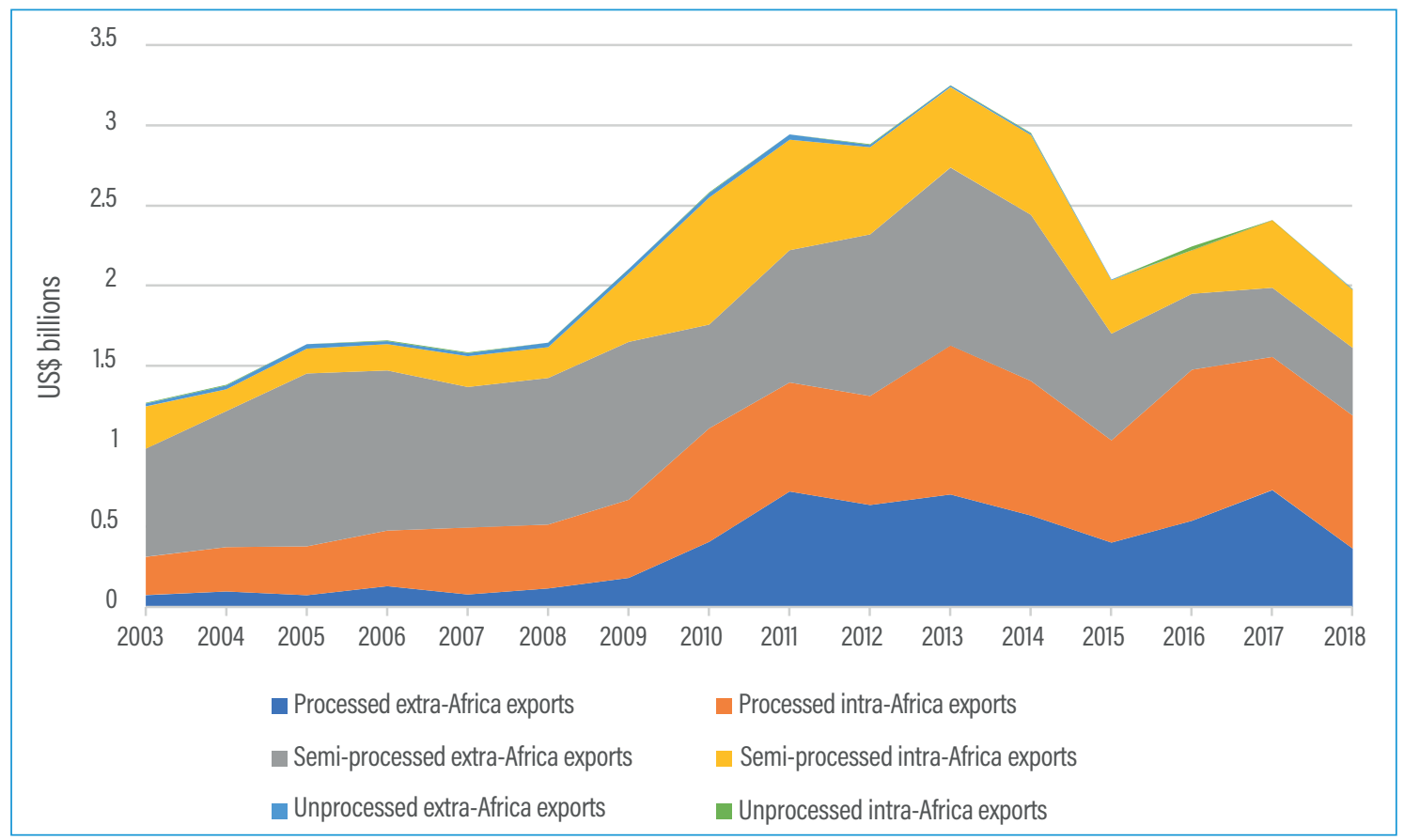

Source: 2020 AATM database.

Figure 4.18 shows the distribution of African imports in the sugar value chain by processing stage and by origin (intra-Africa vs. extra-Africa) over the 2003-2018 period. Again, trade in unprocessed products is not significant. The bulk of these imports are extra-Africa imports of semi-processed and processed products: their share has increased from 72 percent in 2003 to more than 80 percent in 2018.

Figure 4.18 African imports by processing stage and by origin, sugar value chain, 2003-2018

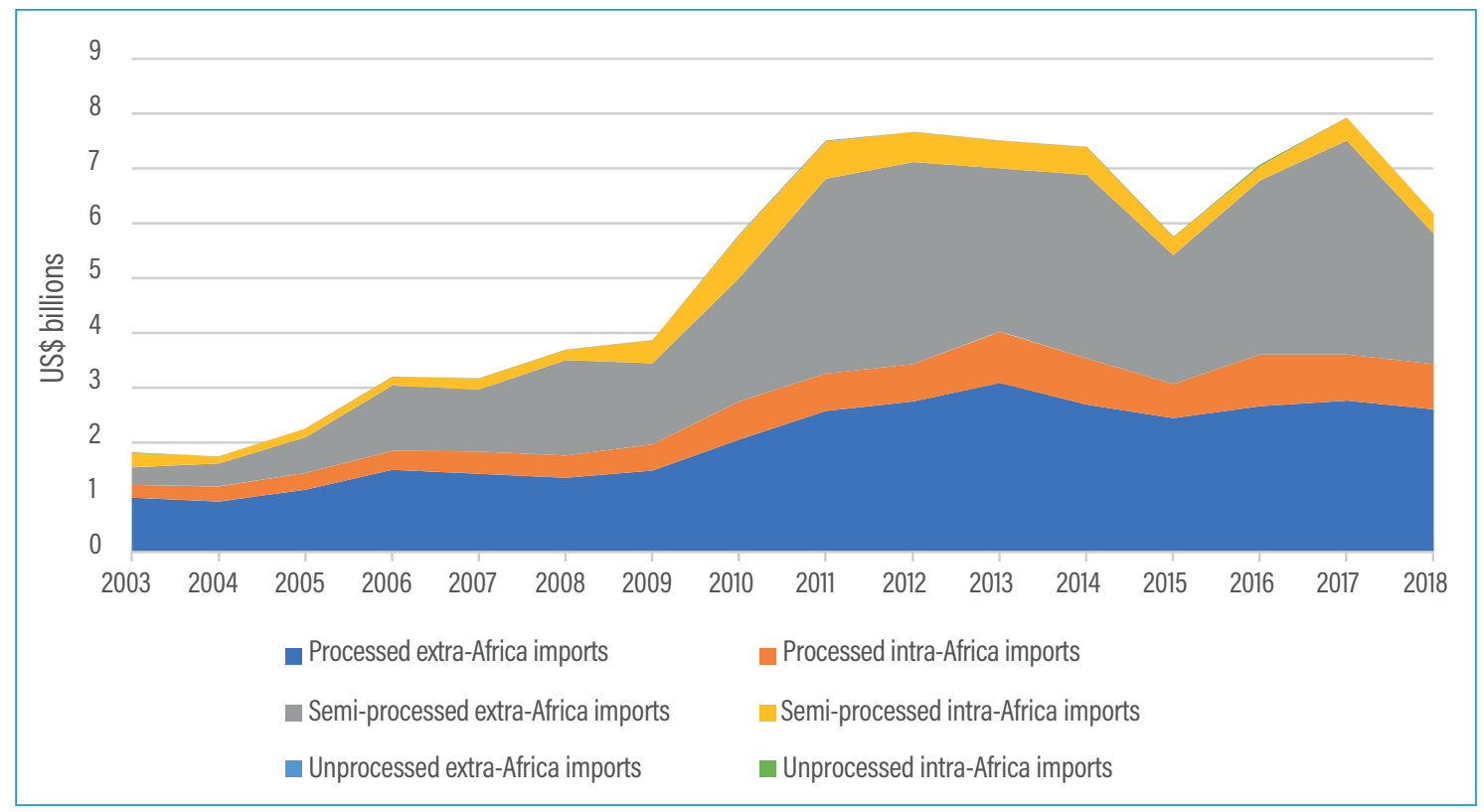

Source: 2020 AATM database. 


\section{Vegetable oils}

Figure 4.19 presents the vegetable oil value chain. Here we only consider two processing stages: an unprocessed stage and a processed one. The unprocessed stage consists of crops - soya, palm, groundnut, or rapeseeds..$^{10}$ The processed stage consists of vegetable oil and cakes for animal feed. Indeed, cakes are a co-product of vegetable oils.

The concept of the value chain is not totally clear. For the cereal value chain, we focused on the upstream product: rice, maize, wheat, and so on. But for the vegetable oil value chain, we focus now on the downstream product, that is vegetable oils. This is an important point because we do not include product 200811 ("Nuts; ground-nuts, whether or not containing added sugar, other sweetening matter or spirit") in this value chain, which is a processed product. Nor do we include product 120810 ("Flours and meals; of soya beans"), which is another use of oilseed soya. However, we do include oil-cake, which is a co-product of vegetable oil in the crushing industry.

Figure 4.19 Vegetable oils value chain

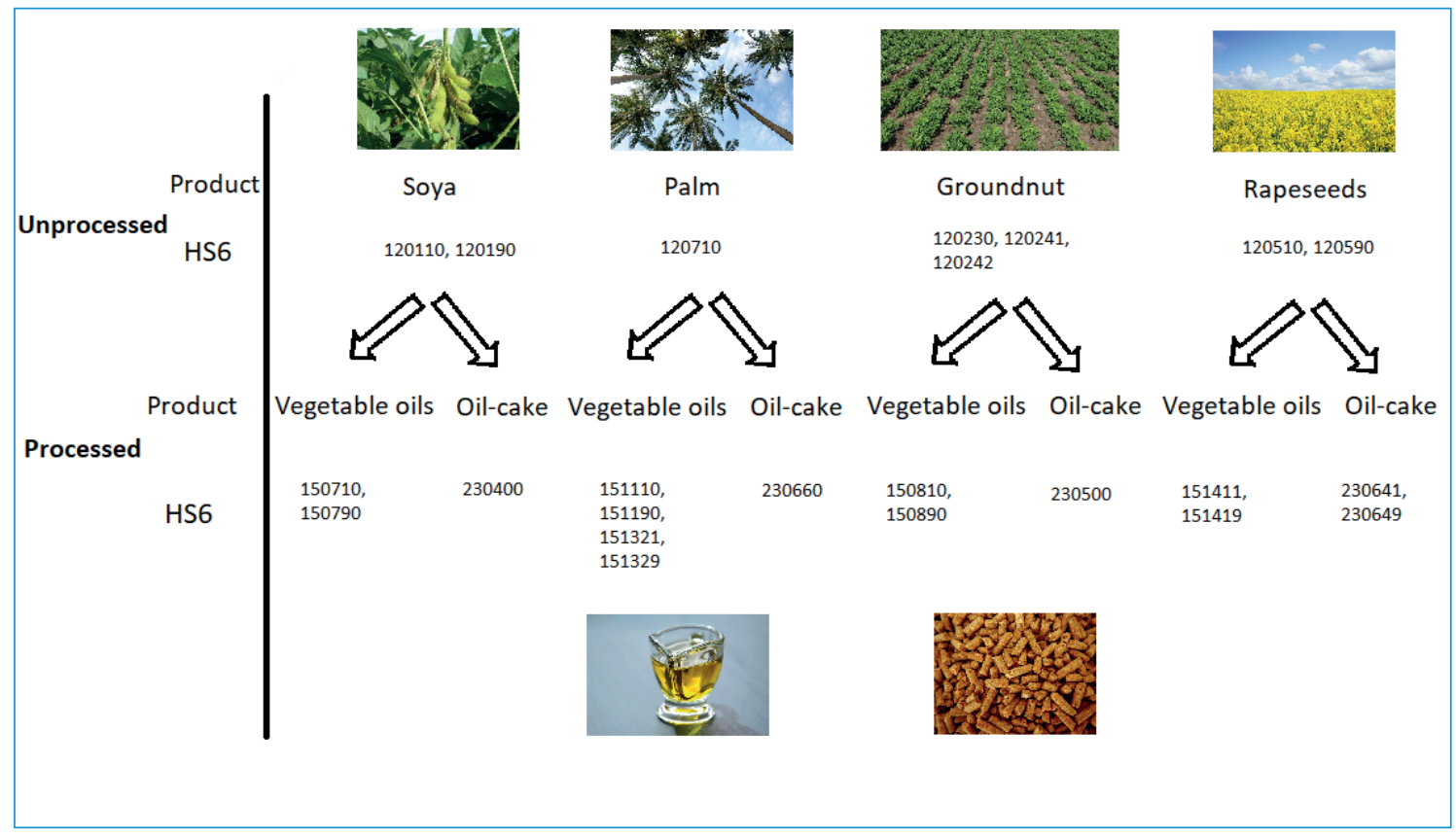

Source: Authors' elaboration.

Note: Photos from Pixabay; numbers refer to Harmonized System 6 (HS6) codes.

Table 4.4 shows the 10 largest producers of palm fruit, soybeans, groundnuts, and rapeseeds in 2018. In terms of vegetable oils, palm, soya, and rapeseeds represent more than 90 percent of the world market. There is no African country in the list of the largest producers of the crops needed for the production of these oils. The world market for groundnut oil is comparatively small, but 5 African countries are in the list of the 10 largest producers of groundnuts. 
Table 4.4 Production of palm fruit, soybeans, groundnuts, and rapeseeds in volume, 10 largest producers, 2018

\begin{tabular}{|lr|lr|lr|lr|}
\hline \multicolumn{1}{|c|}{ Palm } & & Soybeans & & Groundnuts & & \multicolumn{2}{|c|}{ Rapeseeds } \\
Country & Production (MT) & Country & Production (MT) & Country & Production (MT) & Country & Production (MT) \\
\hline 1. Indonesia & $40,567,230$ & 1. USA & $123,664,230$ & 1. China & $17,392,071$ & 1. Canada & $20,342,600$ \\
2. Malaysia & $19,516,100$ & 2. Brazil & $117,887,672$ & 2. India & $6,695,000$ & 2. China & $13,281,208$ \\
3. Thailand & $2,776,800$ & 3. Argentina & $37,787,927$ & 3. Nigeria & $2,886,987$ & 3. India & $8,430,000$ \\
4. Colombia & $1,630,000$ & 4. China & $14,193,621$ & 4. Sudan & $2,884,000$ & 4. France & $4,945,589$ \\
5. Nigeria & $1,050,000$ & 5. India & $13,786,000$ & 5. USA & $2,477,340$ & 5. Australia & $3,893,071$ \\
6. Guatemala & 875,000 & 6. Paraguay & $11,045,971$ & 6. Myanmar & $1,599,149$ & 6. Germany & $3,670,600$ \\
7. Honduras & 650,000 & 7. Canada & $7,266,600$ & 7. Tanzania & 940,204 & 7. Ukraine & $2,750,600$ \\
8. Papua NG & 630,000 & 8. Ukraine & $4,460,770$ & 8. Argentina & 921,231 & 8. Poland & $2,203,869$ \\
9. Ecuador & 560,000 & 9. Russia & $4,026,850$ & 9. Chad & 893,940 & 9. UK & $2,012,000$ \\
10. Brazil & 450,000 & 10. Bolivia & $2,942,131$ & 10. Senegal & 846,021 & 10. Russia & $1,988,697$ \\
\hline
\end{tabular}

Source: FAOSTAT.

Note: $\mathrm{MT}=$ metric tons.

In the introduction of this section, Figure 4.2 illustrated a comparative disadvantage of Africa in the vegetable oils value chain throughout the 2003-2018 period. Again, at the continental level, from 2003 to 2018, Africa has a comparative disadvantage in both processing stages as illustrated by Figure 4.20. Africa had a net trade deficit in both processing stages: US $\$ 7.1$ billion at the processed stage and US\$870 million at the unprocessed stage on average for 2016-2018.

Figure 4.20 Africa, revealed comparative advantage by stage of processing, vegetable oils value chain, 2003-2018

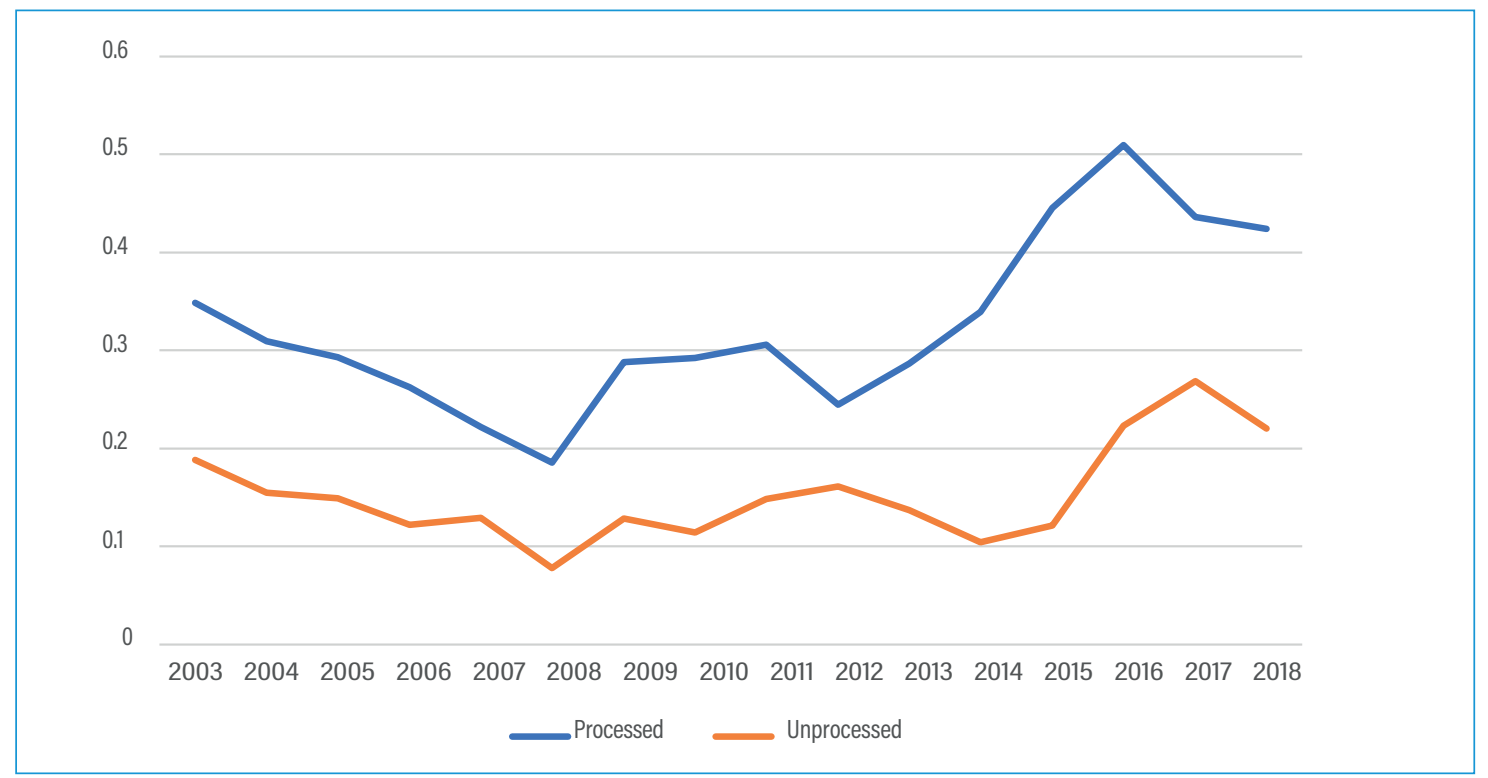

Source: 2020 AATM database.

Note: Vegetable oils include groundnut, palm, rapeseed, and soy oils. 
In this value chain, we consider four different crops at the initial stage of transformation: soya, palm, groundnut, and rapeseeds. Africa has a comparative advantage in unprocessed palm and groundnuts commodities (Figure 4.21). It is worth mentioning that rapeseed in Europe and soya in Brazil, the United States, and China benefit from a significant policy support that might affect their world market share, and thus might also contribute to Africa's comparatively low exports.

Figure 4.21 Africa, revealed comparative advantage, seeds, 2003-2018

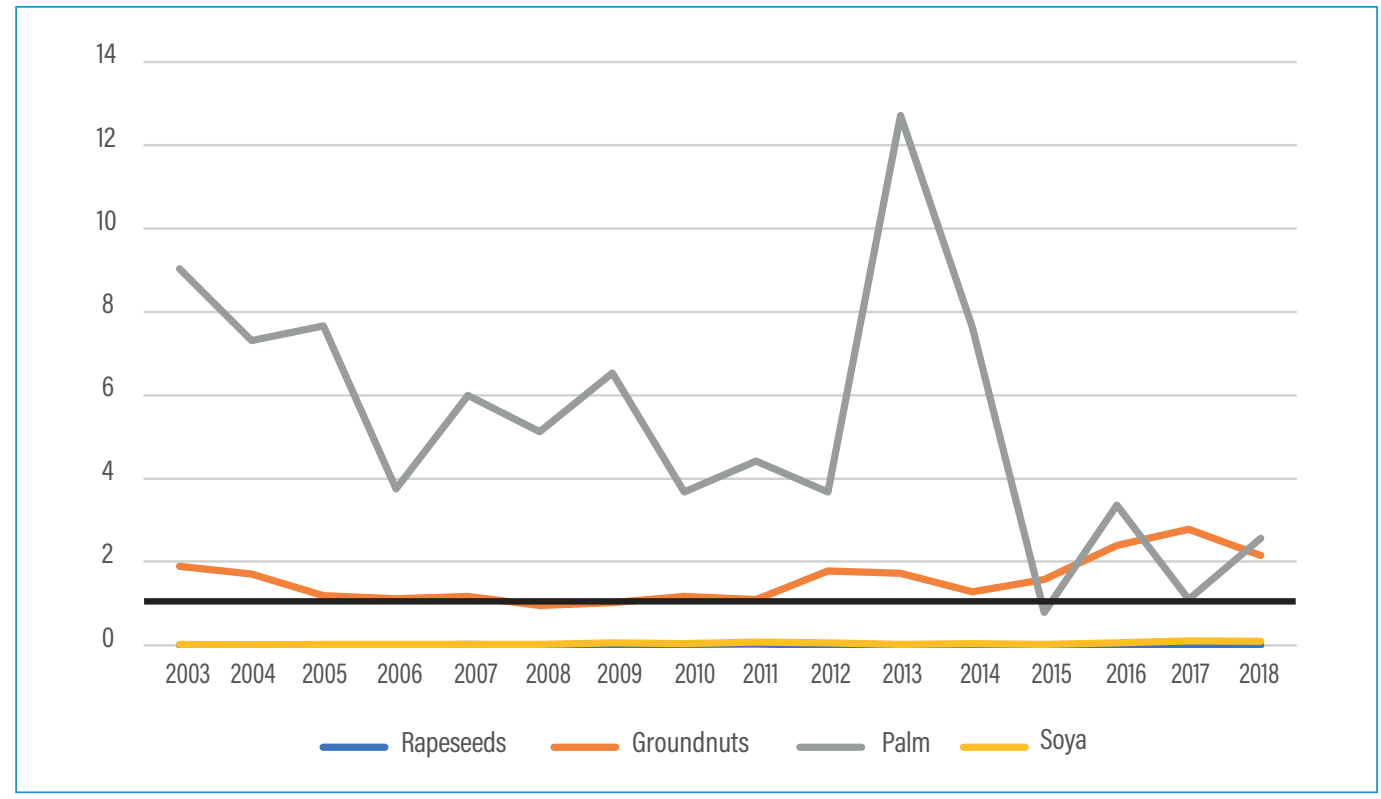

Source: 2020 AATM database.

Note: : The horizontal line corresponds to an RCA of 1 . An RCA greater than 1 indicates a comparative advantage; an RCA below 1 indicates no comparative advantage.

Figure 4.22 and Figure 4.23 show, respectively, the net exports of processed products and unprocessed commodities between 2003 and 2018 at the continental level. Africa is a net exporter of unprocessed groundnuts and vegetable oils fabricated from this crop, but the amounts are small, especially in comparison to the large import flows, by value, of palm oil, soya oil, and soybeans.

Figure 4.22 African net exports of processed vegetable oils by type of seeds, 2003-2018

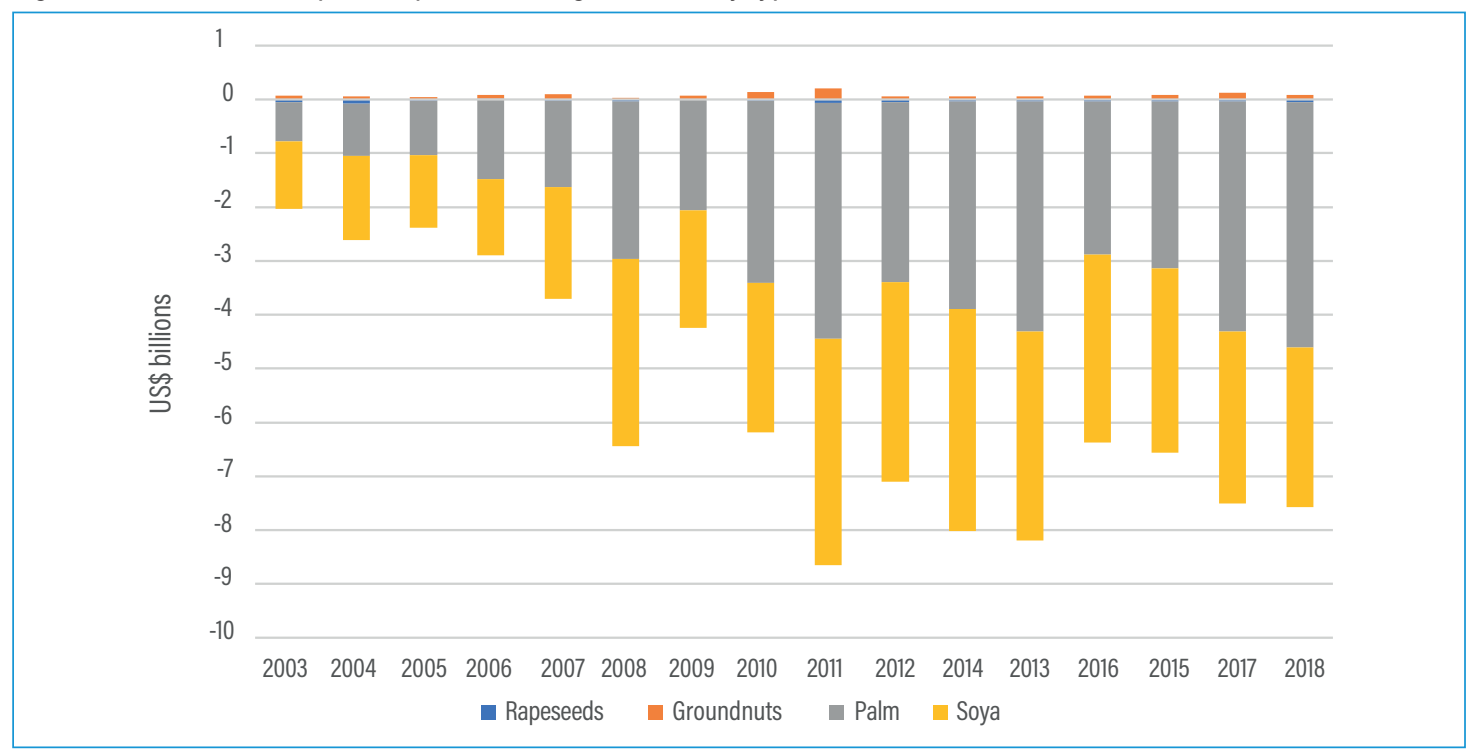

Source: 2020 AATM database. 
Figure 4.23 African net exports of unprocessed commodities, vegetable oils value chain, 2003-2018

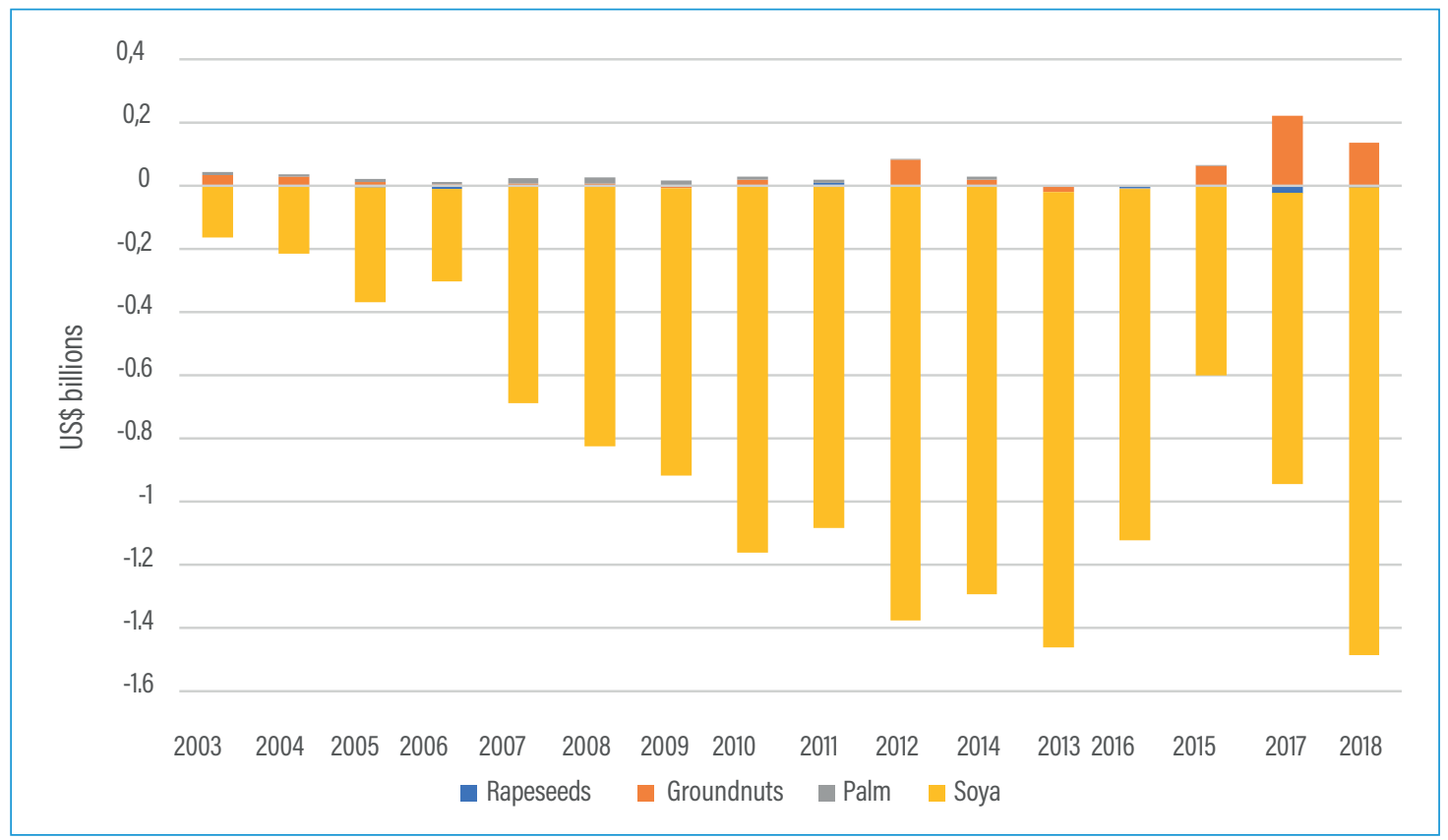

Source: 2020 AATM database.

Figure 4.24 shows RCA by African country in the vegetable oil value chain. On average for 20162018, trade flows reveal a comparative advantage for 12 African countries in this value chain, the advantage being large for (in decreasing order) Gambia, Malawi, Senegal, Niger, Benin, Sudan, Togo, and Uganda. Forty African countries had a comparative disadvantage in this value chain in 2016-2018. 
Figure 4.24 Revealed comparative advantage by African country, vegetable oils value chain, average 2016-2018

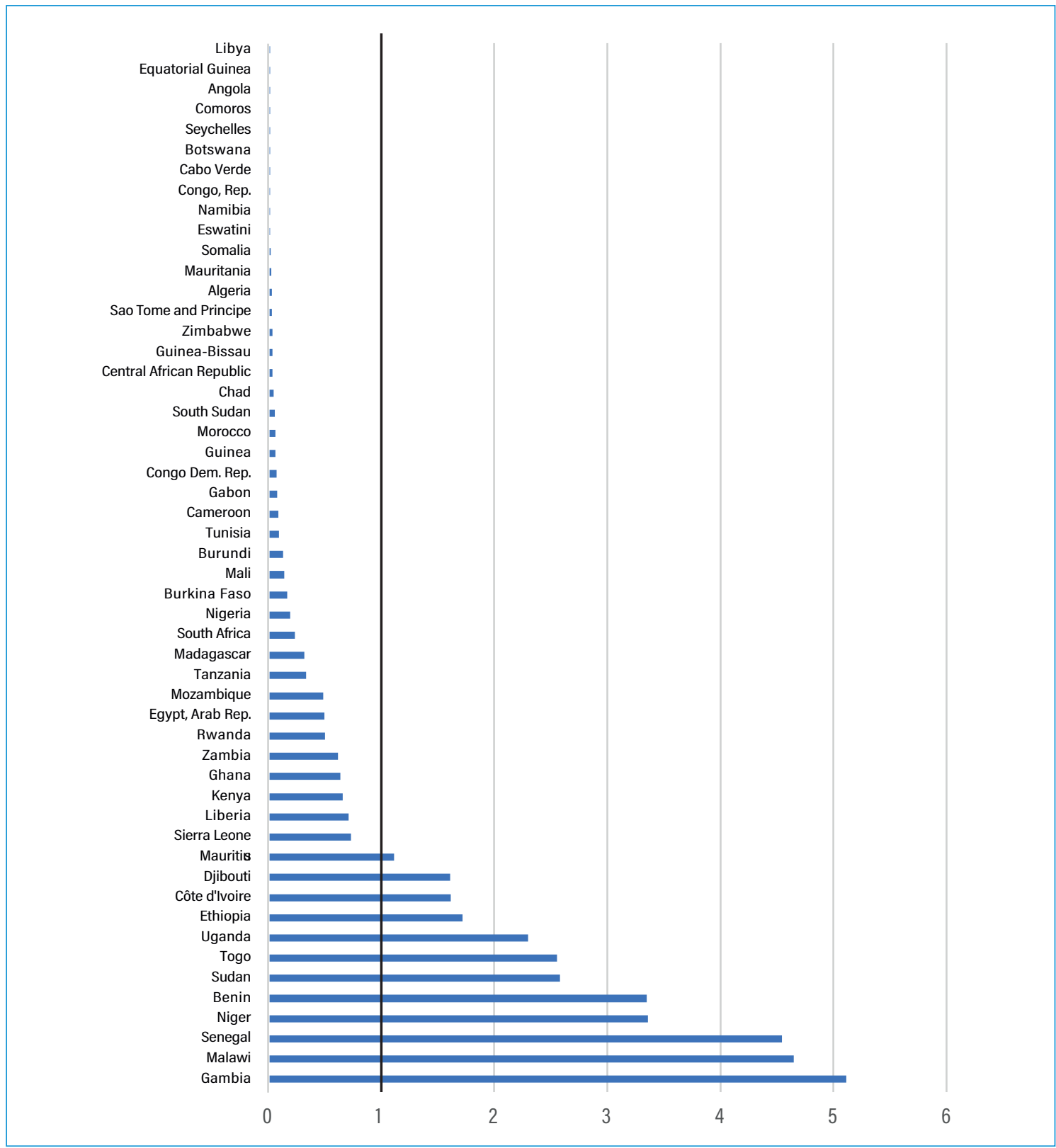

Source: 2020 AATM database.

Note: Vegetable oils include groundnut, palm, rapeseed, and soy oils; we include unprocessed, semi-processed, and processed commodities. The vertical line corresponds to an RCA of 1 and delimits the split between countries with a comparative advantage (RCA greater than 1) and countries without a comparative advantage (RCA less than 1 ) in the sugar value chain.

It is interesting to see what processing stage of this value chain African countries are specialized in. Figure 4.25 shows net exports by African country and processing stage on average for 20162018. Of 54 African countries, only Sudan is a net exporter in both processing stages. And only one, Côte d'Ivoire, is a net exporter of processed products and a net importer of unprocessed commodities (US $\$ 99$ million of net exports of processed products, US $\$ 0.5$ million of net imports of unprocessed commodities). Thirty-one African countries are net importers in both processing stages, in large amounts for Egypt (US $\$ 1.1$ billion of net imports of processed products, US $\$ 735$ million of unprocessed commodities). Twenty-one African countries are net importers of processed 
products and net exporters of unprocessed commodities. The case of Senegal is emblematic with US $\$ 105$ million of net imports of processed products and US\$109 million of net exports of unprocessed commodities. This raises again the issue of the "right" positioning of African economies in agrifood value chains: very few African countries are able to move up the value chains and become competitive at stages of product processing. Many appear to be competitive only in the export of raw products.

Figure 4.25 Net exports by African country and by stage of processing, vegetable oils value chain, average 2016-2018

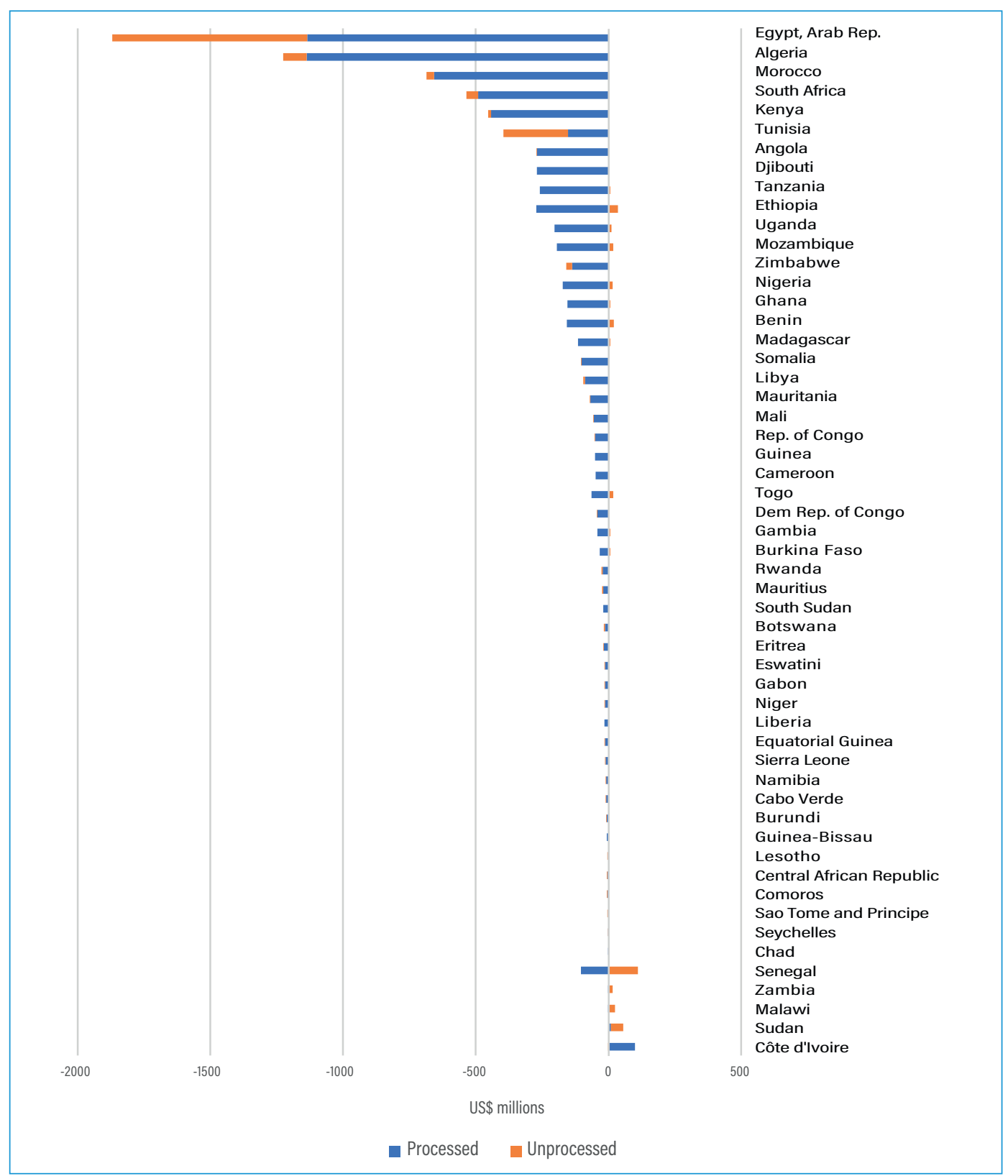

Source: 2020 AATM database.

Note: Vegetable oils include groundnut, palm, rapeseed, and soy oils; we include unprocessed, semi-processed, and processed commodities.

At the national level, calculations of RCAs reveal a few outstanding comparative advantages: Gambia in unprocessed groundnuts and palm kernels, Benin in both unprocessed and processed palm products, Malawi in unprocessed groundnut and soya products, Niger in (processed) palm oil, and Senegal in unprocessed and processed groundnuts products. 
Figure 4.26 provides another indicator of competitiveness over the 2003-2018 period - the ratio of export unit values of unprocessed commodities for oilseeds, Africa over the rest of the world. It indicates competitiveness of African unprocessed groundnuts and palm commodities. Calculation of the same indicator for processed products shows price-competitiveness of oils from rapeseeds and groundnuts, while the price of African palm oil is close to the world price of the same product.

Figure 4.26 Ratio of export unit value for oilseeds, Africa over Rest of the World, vegetable oils value chain, unprocessed stage, 2003-2018

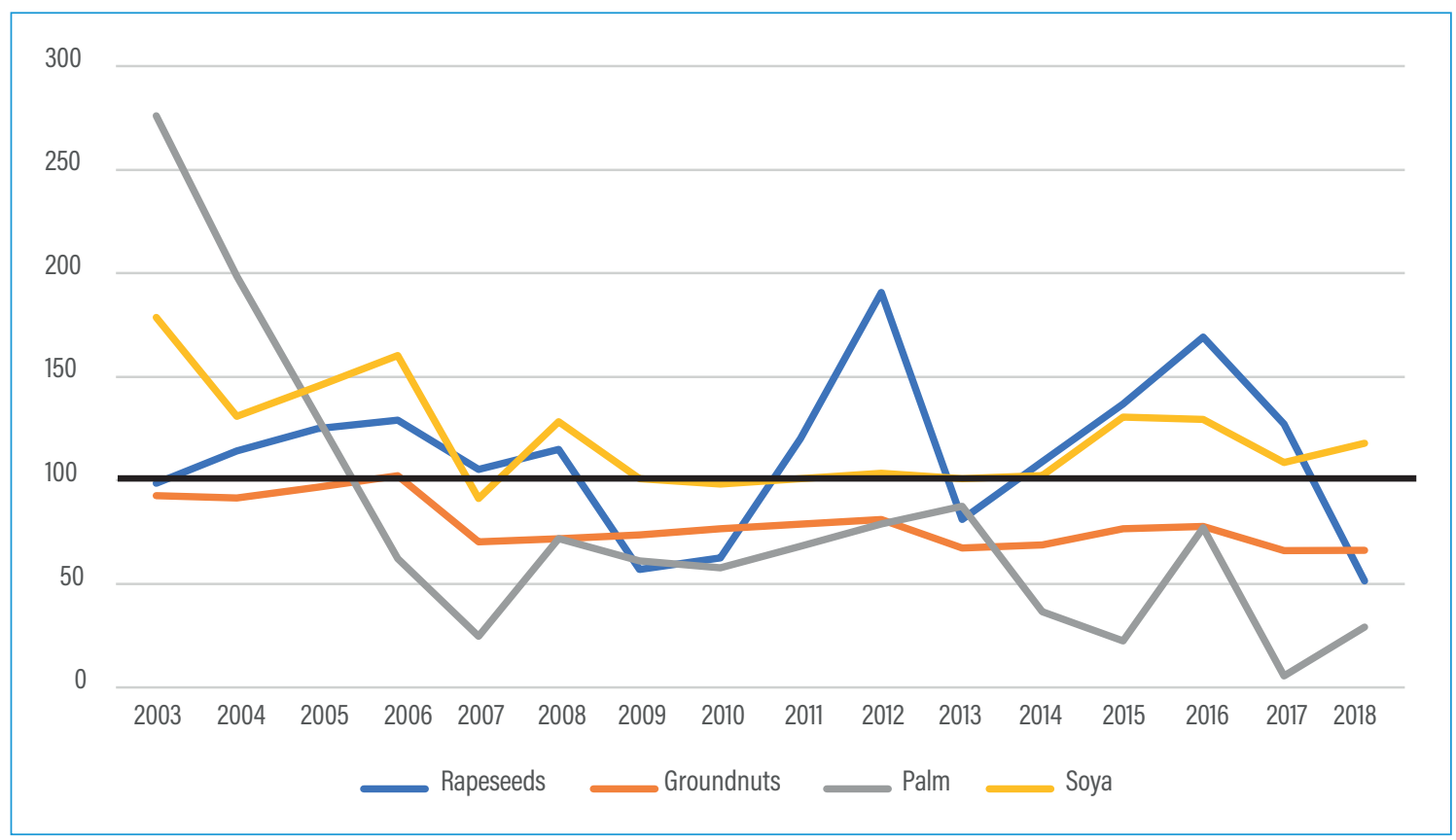

Source: 2020 AATM database.

Note: Vegetable oils include groundnut, palm, rapeseed, and soy oils; we include unprocessed, semi-processed, and processed commodities. The horizontal line corresponds to an indicator of 100 and delimits the split between years when Africa's products are price-competitive (less than 100) and years when they are not (greater than 100).

We turn now to the geographic pattern of African trade in the vegetable oil value chain. Figure 4.27 shows the distribution of African exports in this value chain between 2003 and 2018, by destination (extra-Africa vs. intra-Africa) and processing stage (unprocessed vs. processed). Figure 4.28 shows the distribution of African imports by origin (extra-Africa vs. intra-Africa) and processing stage (unprocessed vs. processed). 
Figure 4.27 African exports by stage of processing and by destination, vegetable oils value chain, 2003-2018

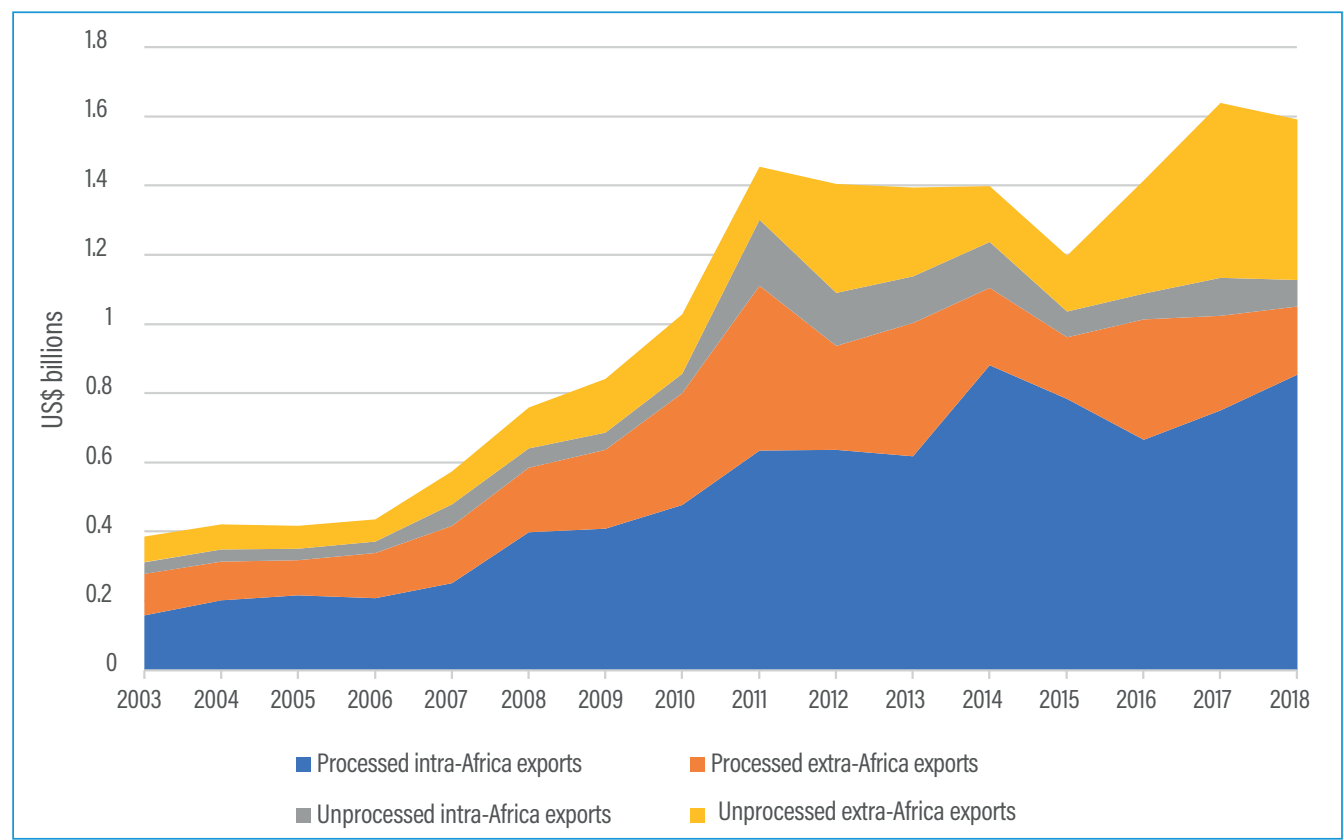

Source: 2020 AATM database.

Note: Vegetable oils include groundnut, palm, rapeseed, and soy oils.

Figure 4.27 shows that in the vegetable oils value chain, the bulk of African exports is intra-African processed products. Total exports in this value chain are increasing over the whole period at an average growth rate of 9.9 percent (current US\$) and the share of intra-African processed exports in total exports has grown from 41 percent to 54 percent. Since 2015, extra-African exports of unprocessed commodities are also increasingly significant.

Figure 4.28 African imports by stage of processing and by origin, vegetable oils value chain, 2003-2018

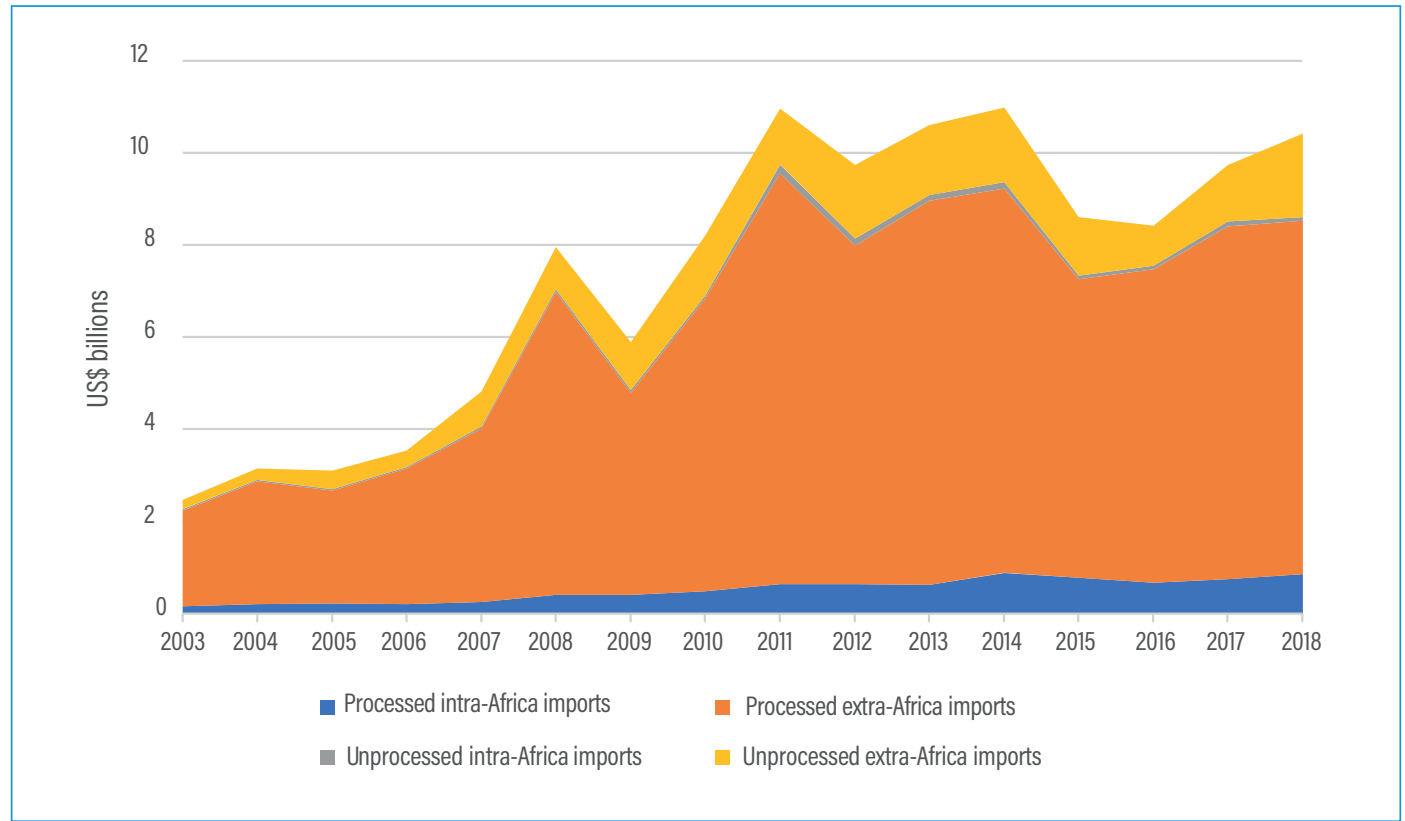

Source: 2020 AATM database.

Note: Vegetable oils include groundnut, palm, rapeseed, and soy oils. 
Total African imports of vegetable oil have increased at an even more rapid pace: 10.1 percent over the 2003-2018 period (Figure 4.28). The bulk of these imports is extra-African imports of processed products. However, their share in total imports has decreased over the period from 84 percent to 74 percent, while the share of extra-African imports of unprocessed commodities (soya) was raised from 8 percent to 17 percent.

This section has clearly demonstrated the lack of competitiveness of African countries in the main cereals and cassava, vegetable oils, and sugar value chains, even if a few exceptions appear: Nigeria, Democratic Republic of the Congo, and Ghana in cassava; Eswatini, Mauritius, and Zambia in semi-processed and processed sugar products; Tanzania in sugarcane; Algeria, Egypt, and Morocco in sugar confectionery; Nigeria, Sudan, and Tanzania in groundnuts; and Côte d'Ivoire and Sudan in (processed) vegetable oils. Before looking for factors outside Africa, many domestic factors explain this lack of competitiveness: low agricultural productivity related to poor access to credit markets; insufficient investment in research and development; insufficient access to fertilizers, new technology, and irrigation; high costs related to logistics, transportation, and customs procedures; and relatively high import duties that continue to impede intraregional trade and the development of regional value chains."

We now proceed to the analysis of trade policies in the main OECD and emerging markets. We will chiefly focus on tariffs and domestic support in China, India, Brazil, the European Union (EU), and the United States (US).

\section{Trade and agricultural policies of OECD and emerging countries}

As has been shown, the lack of competitiveness in main cereals and cassava, vegetable oils, and sugar can be chiefly explained by a lack of comparative advantage, especially when African countries are compared to other agricultural producers. However, looking at the demand side and especially trade policy in main destinations will help us develop a more comprehensive analysis of the three chains.

To do so, we will focus on four main markets, namely China, India, Brazil, the EU, and the US, for three reasons. First, these are in general large producers of agricultural products and hence have a comparative advantage in many of them. Second, they are also large importers of agricultural products and thus represent an important destination for African countries' products. Third, at the world level, they tend to have more protectionist policies for agricultural products, when compared to non-agriculture products or when compared to other markets.

In terms of trade policies, this section primarily analyzes tariffs and domestic support that remain a significant impediment for agricultural products in the largest markets. ${ }^{12}$

11 See for example Conway et al. (2019), Bouët et al. (2017), GRO Intelligence (2016), IFPRI (2019), Odjo et al. (2019), and Wiggins (2019). See also Chapters 2 and 3 of this report.

12 While sanitary and phytosanitary (SPS) measures are also frequently used, we prefer to focus on these two dimensions as they are less studied in the literature on agricultural trade. For the effect of SPS and conformity assessment, see Chapter 2. 


\section{Tariff structure and tariff escalation}

When analyzing trade policy and value chains, it is indispensable to analyze both tariff structure and tariff escalation. Figure 4.29 presents the weighted average tariff rate applied to our main products of interest. On average, sugar tariffs (36.6 percent) are higher than cereals and cassava (15 percent) and vegetable oils (8.4 percent) in all countries. The difference is pronounced in both emerging and developed countries since, in China, sugar tariffs are 9 times higher than tariffs on the main cereals and cassava and on vegetable oils; in India, 2 and 5 times respectively; in the EU, 4 and 25 times; and in the US, 7 and 10 times respectively. The smallest difference is observed for Africa and Brazil. Among the OECD countries, the EU is more protectionist than the US for sugar and main cereals and cassava. Among emerging countries, while India is the most protectionist for all products, Brazil has higher tariffs than China on vegetable oils and the main cereals and cassava.

Figure 4.29 Weighted average tariff rate applied to selected group of agricultural products, 2016

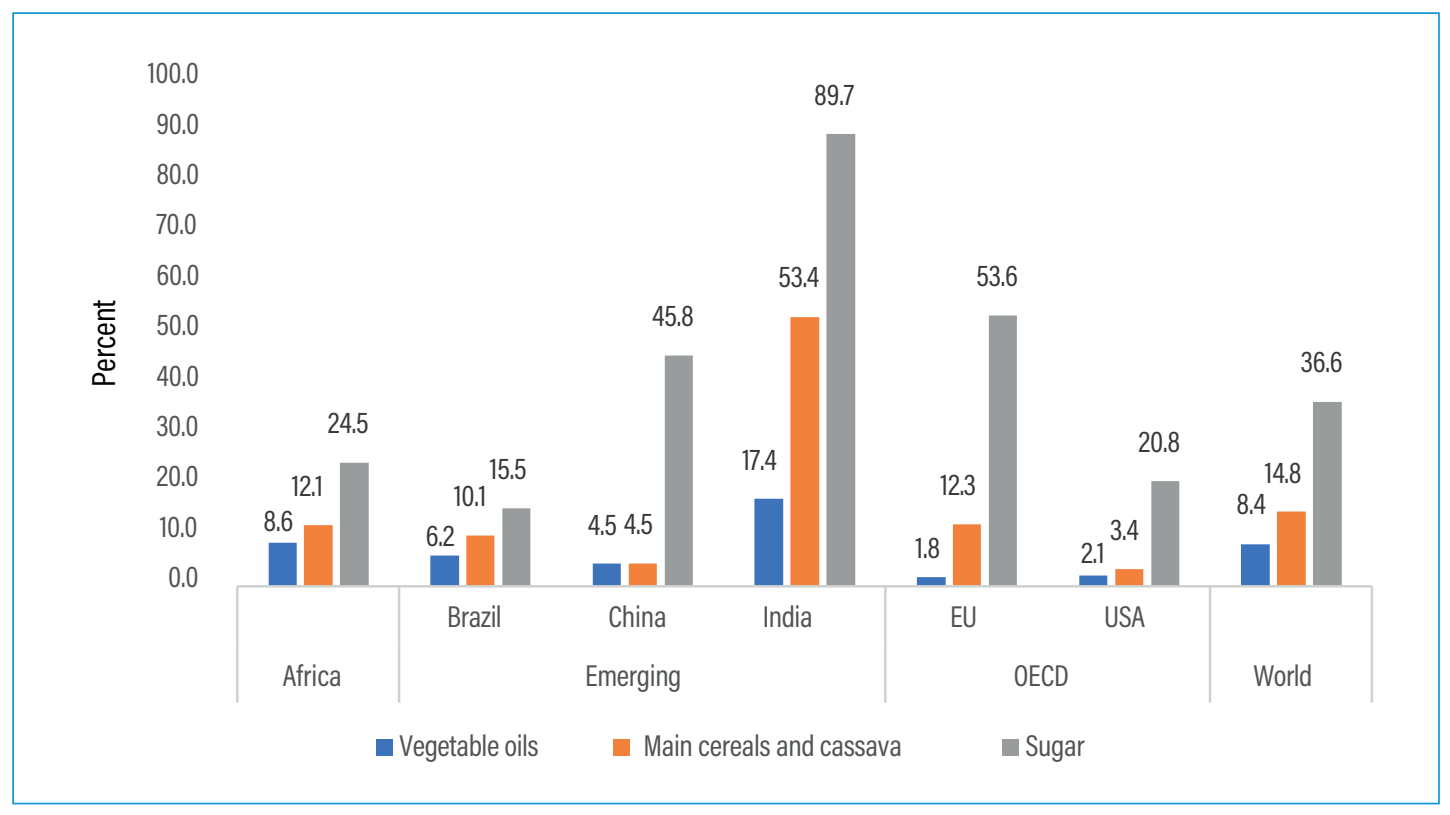

Source: Authors' elaboration using MAcMap-HS6.

After examining the tariff structure, it is important to analyze tariff escalation when analyzing the nexus between trade policy and value chains. Tariff escalation prevails when tariffs are zero or low on primary products and increase as products are processed. When a country escalates its tariffs, prices of processed imports relative to raw products increase, which augments value-added at the processing stage and decreases the demand for processed products in the importing country. Thus, exporters (African countries in our case) will be obliged to export more unprocessed products than processed ones, leading to a low level of diversification, lower value-added, and less employment (Hoekman et al. 2002). Indeed, Elamin and Khaira (2003) found that tariff escalation is, generally, more pronounced for meat, sugar, fruit, coffee, cocoa, and hides and skins, most of which are of export interest to many of the poor developing countries. Some studies have examined the effect on particular products. For instance, Narayanan and Khorana (2014), using a general equilibrium model, found that the elimination of tariff escalations generates potential global gains, especially for the cotton sector. Yet, Aziz et al. (2017) showed that the US and the EU do not effectively protect their cocoa industries, and hence no tariff escalation on applied tariffs against cocoa imports from Ghana can be observed. This is why a complete liberalization of trade barriers impeding Ghanaian cocoa exports does not necessarily lead to an increase in the exports of value-added cocoa from Ghana. 
As it is shown in Figure 4.30, tariff escalation is observed for semi-processed products compared to unprocessed ones. However, on average, tariffs imposed on processed products, though higher than those imposed on unprocessed ones, are generally lower than those on semi-processed products. Yet, it is important to note that, in our set of value chains, this is chiefly due to high tariffs on semi-processed sugar and cassava. The remainder of the products are either unprocessed or processed. At the country level, while China and the EU have the largest difference between tariffs on semi-processed and unprocessed products, India is still ranked first in terms of the level of tariffs.

Figure 4.30 Weighted average tariff rate applied to selected group of agricultural products, by degree of processing, 2016

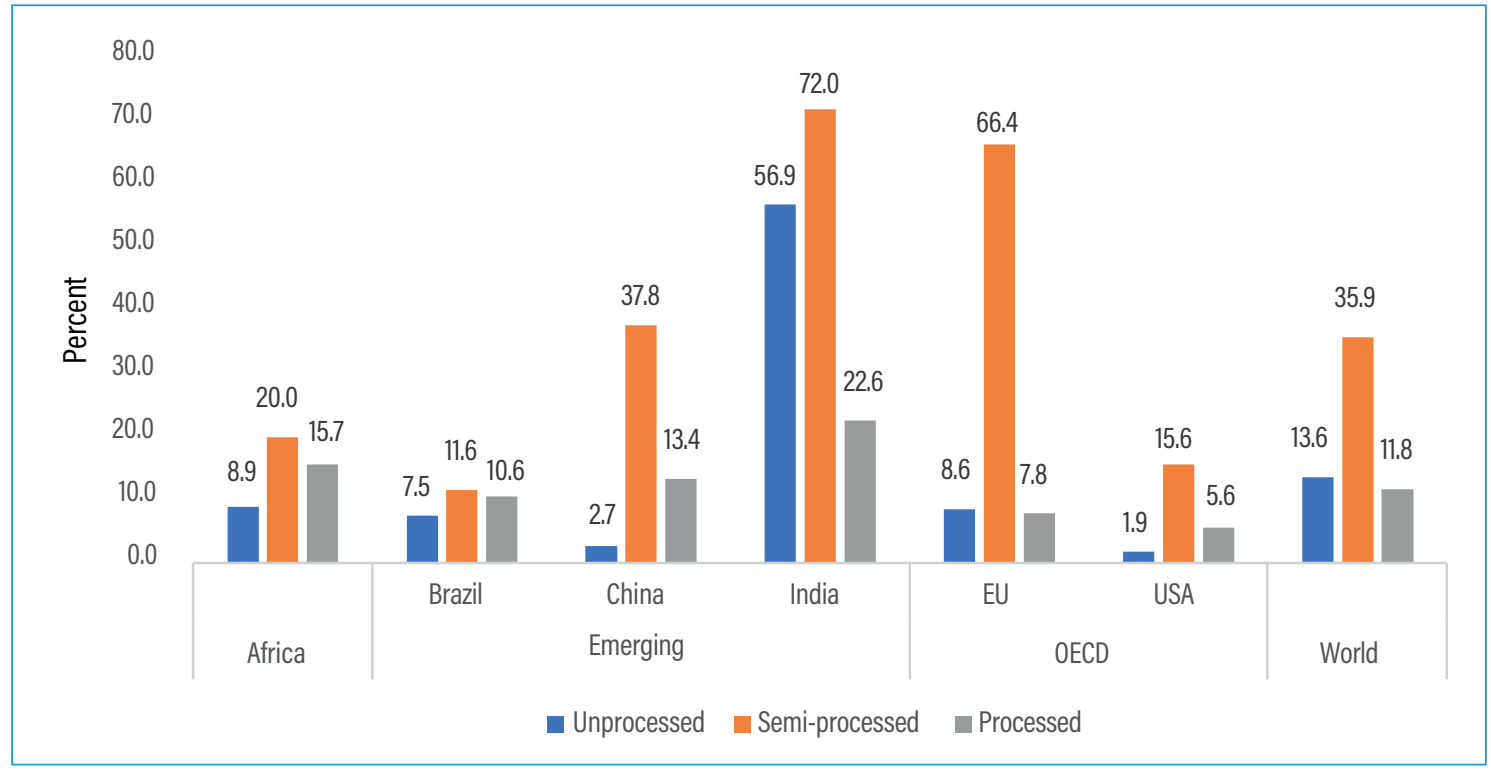

Source: Authors' elaboration using MAcMap-HS6.

Note: Figures show averages for the products related to the three value-chains under study.

After presenting general trends in the three products of interest, we will proceed to a deeper look at tariff hikes and escalations at a more specific level.

For the main cereals and cassava, it is difficult to claim that tariff escalations are the rule. First, while Brazil and China have equal tariffs on unprocessed and semi-processed cassava (see Figure 4.31), tariff escalations characterize both India and EU, since they impose significantly high tariffs on semi-processed cassava (41 percent and 17 percent respectively) and zero tariffs on unprocessed cassava. The US market exhibits a different pattern, with an average tariff of 2 percent on unprocessed cassava and zero tariffs on semi-processed cassava. 
Figure 4.31 Weighted average tariff rate applied to cassava, by products and degree of processing, 2016

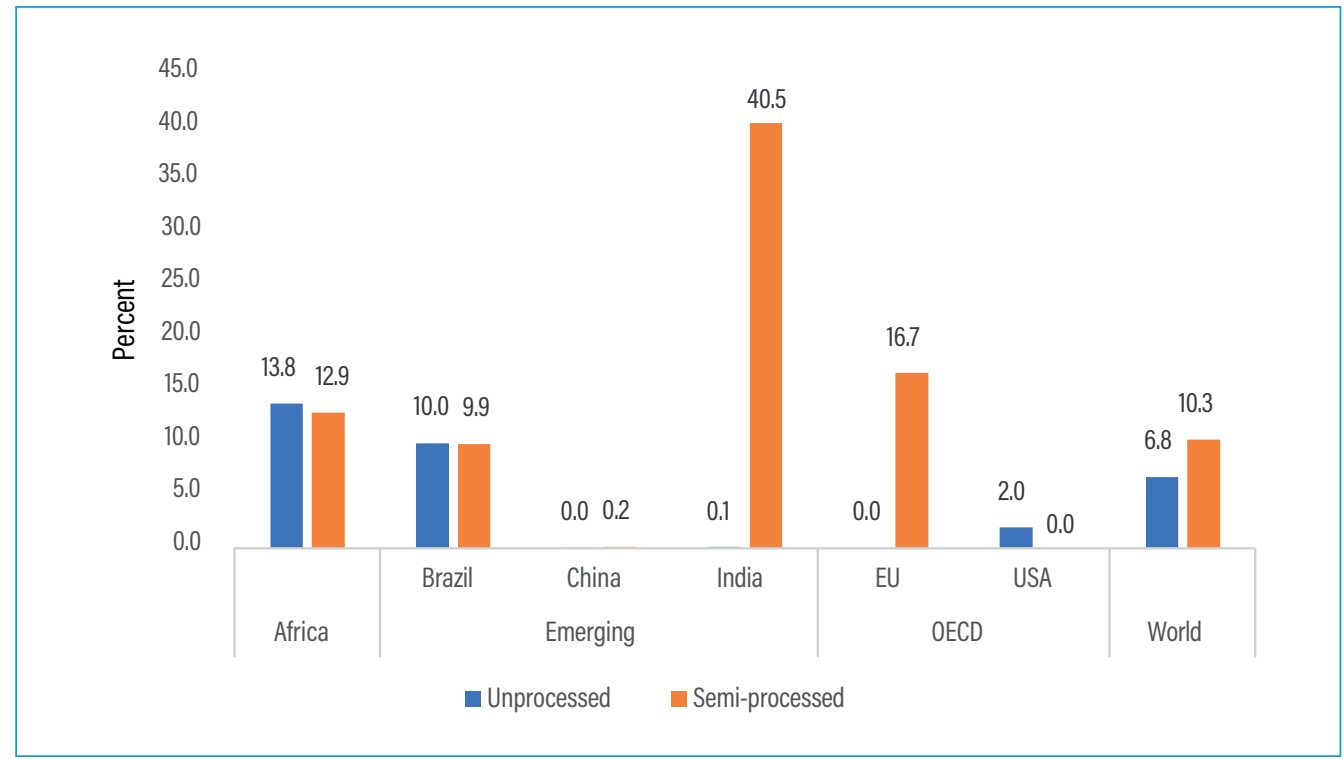

Source: Authors' elaboration using MAcMap-HS6.

Second, Figure 4.32 displays tariffs applied by different countries on other main cereals (rice, wheat, and maize). While rice is heavily protected (28 percent) with the highest tariffs observed in India (72 percent) and the EU (26 percent), maize faces lower tariffs in most of the destinations though slightly higher in Brazil and India. Wheat is much more protected in the EU (27 percent) than in the US (1 percent).

Figure 4.32 Weighted average tariff rate applied to maize, rice, and wheat, 2016

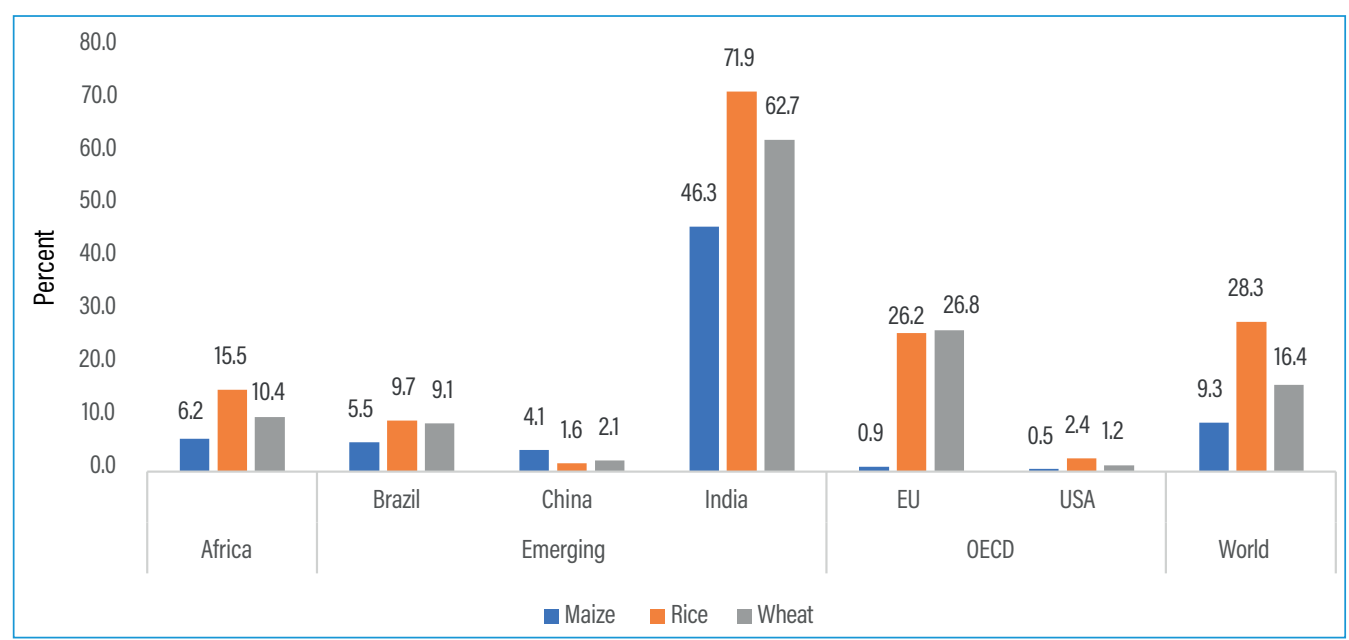

Source: Authors' elaboration using MAcMap-HS6.

When unprocessed and processed products are compared, tariff escalation holds for maize in Brazil, China, and the EU (Figure 4.33); for rice in China (Figure 4.34); and for wheat in China and the EU (Figure 4.35). It is worth noting that India, in general, imposes a higher tariff on unprocessed cereals than on processed ones. This holds for maize (47 percent and 34 percent respectively for unprocessed and processed), for rice (72 percent and 33 percent respectively) and for wheat (70 percent and 30 percent respectively). These high tariffs are coupled with several nontariff measures, especially domestic support, as will be shown below. 
Figure 4.33 Weighted average tariff rate applied to maize, by degree of processing, 2016

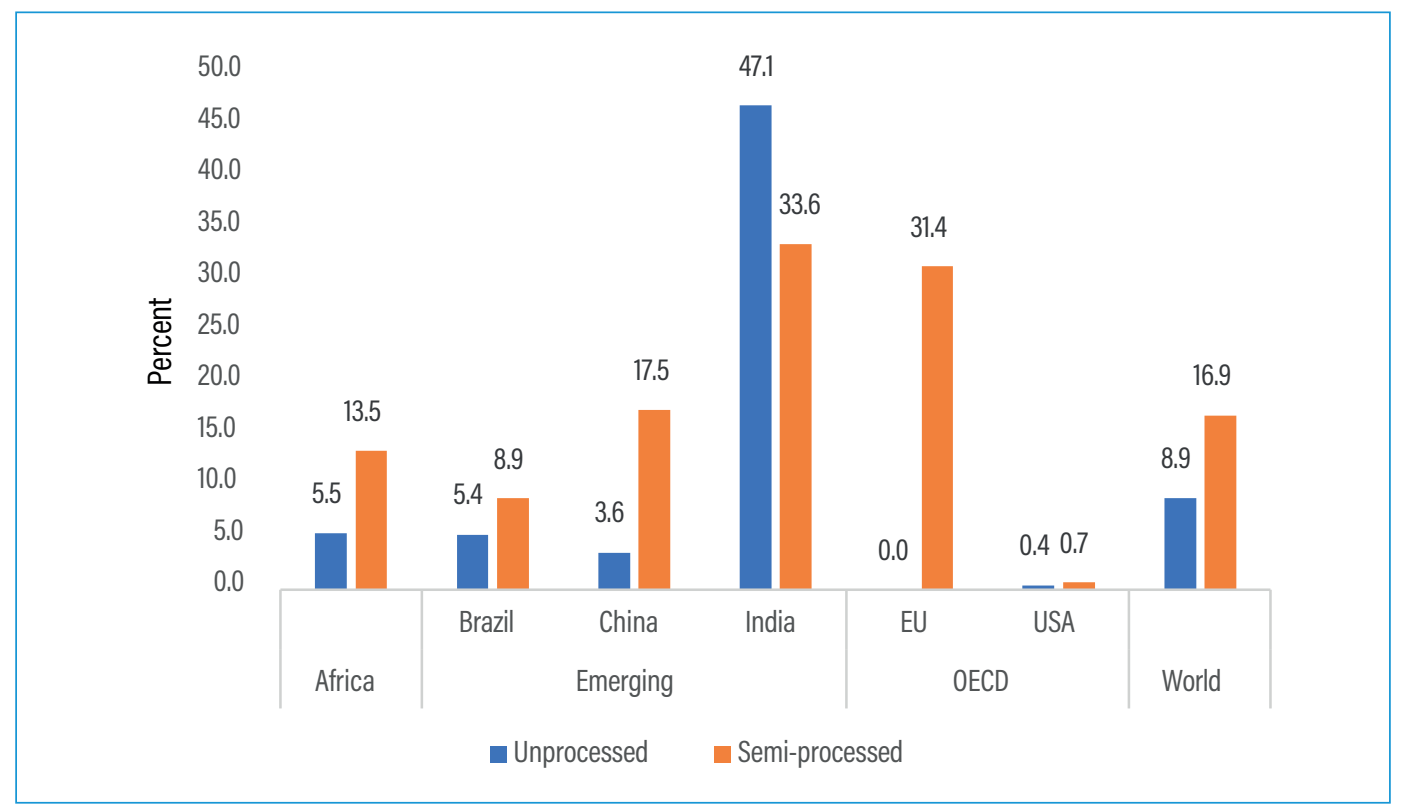

Source: Authors' elaboration using MAcMap-HS6.

Figure 4.34 Weighted average tariff rate applied to rice, by degree of processing, 2016

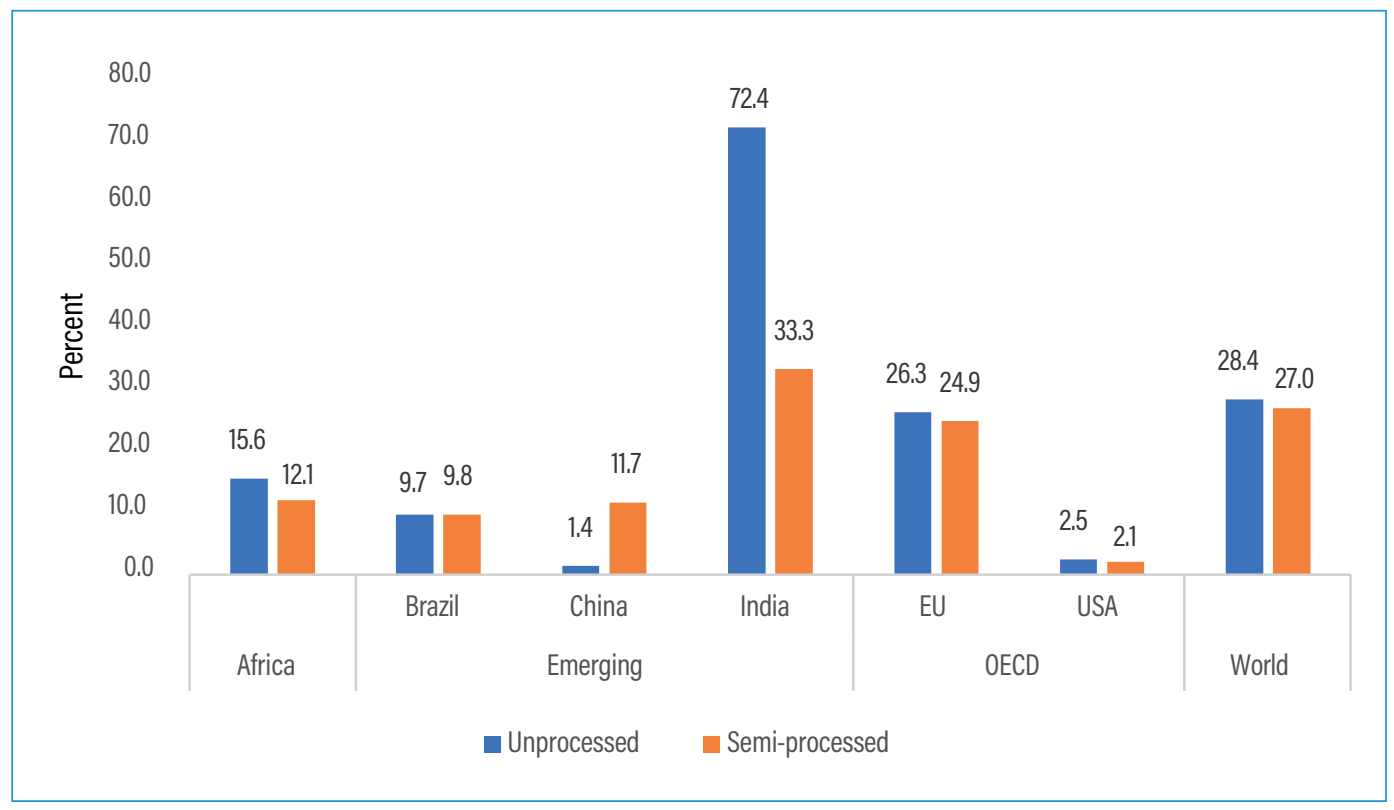

Source: Authors' elaboration using MAcMap-HS6. 
Figure 4.35 Weighted average tariff rate applied to wheat, by degree of processing, 2016

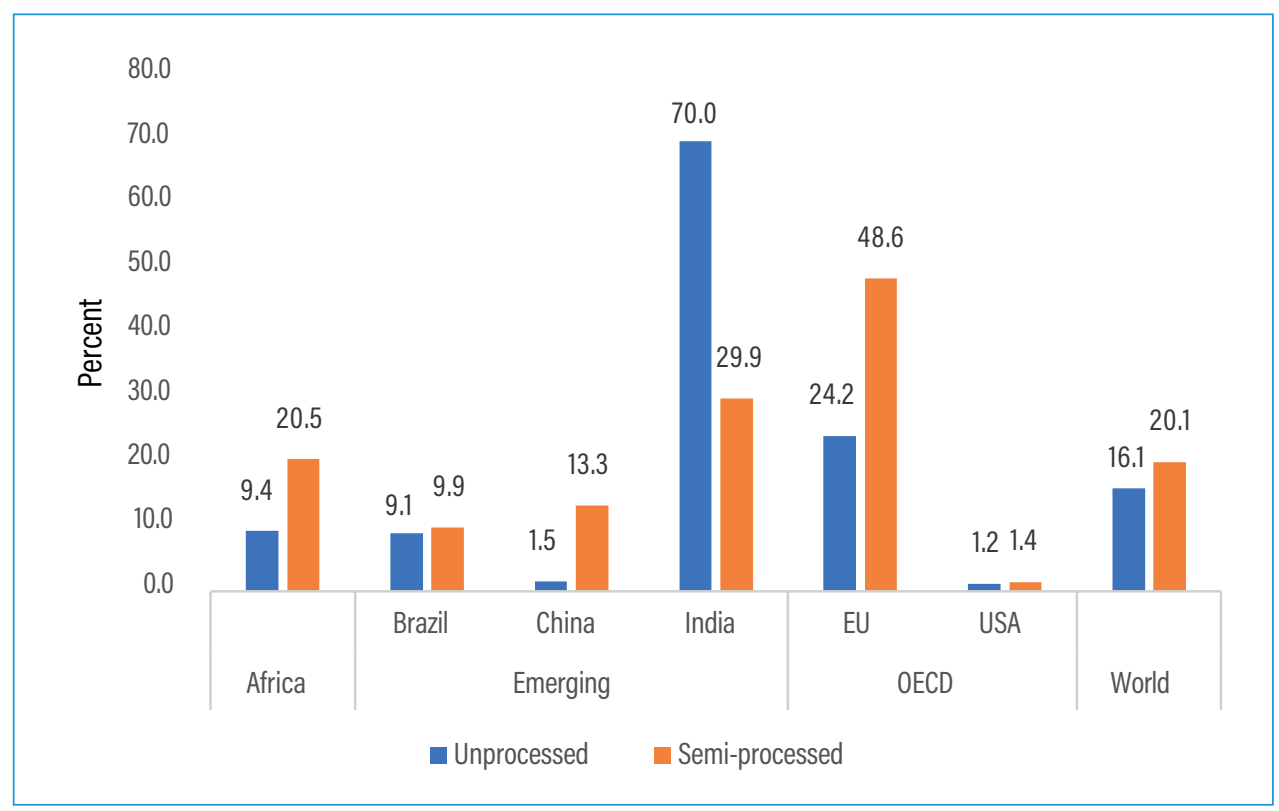

Source: Authors' elaboration using MAcMap-HS6.

Tariff escalation in the sugar value chain is much more pronounced in both OECD and emerging markets. In fact, while tariffs on unprocessed sugar are low in China (0.4 percent), India (1 percent), the US (0.2 percent), and the EU (10 percent), those on semiprocessed sugar are remarkably high, ranging from 25 percent in the US to 51 percent in China, 77 percent in the EU, and 99 percent in India. As was observed in the cassava case, tariffs on processed sugar are generally lower than those on semi-processed, except in Brazil where the tariff is 8 percent on unprocessed sugar, 14 percent on semi-processed, and 16 percent on processed sugar (Figure 4.36).

Figure 4.36 Weighted average tariff rate applied to sugar, by degree of processing, 2016

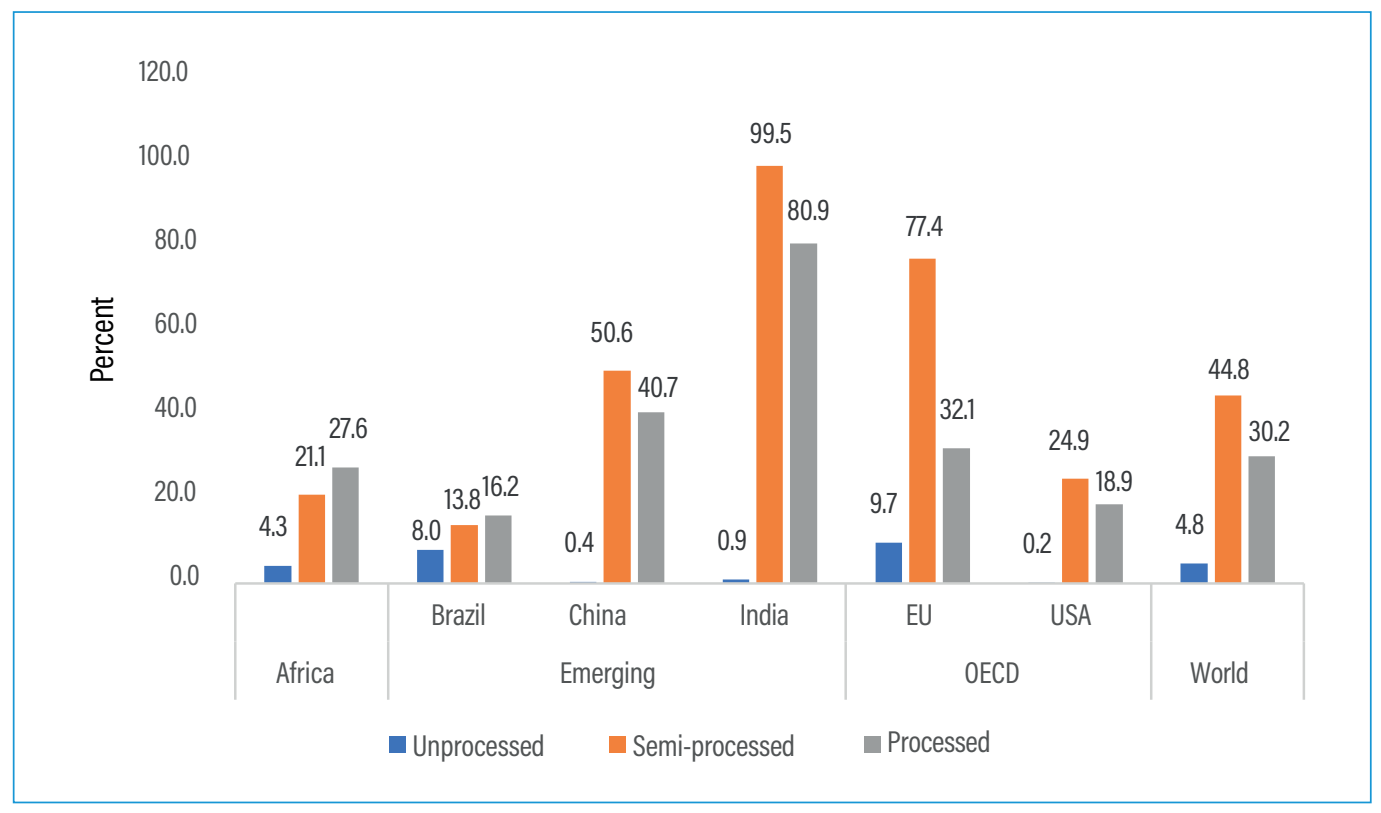

Source: Authors' elaboration using MAcMap-HS6. 
For the vegetable oils value chain, Figure 4.37 shows an important heterogeneity at both the country and the product levels. First, for rapeseed, tariff escalation is observed for all countries except India. In fact, whereas unprocessed rapeseed is weakly protected in most of the markets (with an average tariff of zero in the EU, 1 percent in the United States, 4 percent in Brazil, and 5 percent in China), India's tariff on unprocessed rapeseed is 30 percent. Furthermore, even though tariff escalation is not observed in India, its tariff on rapeseed (14 percent) remains higher than other markets (3 percent in the US, 4 percent in the EU, 8 percent in China, and 9 percent in Brazil). For groundnuts, Figure 4.37b shows a significantly different pattern for two reasons. First, it shows a tariff abatement (the inverse of tariff escalation) for all countries, meaning tariffs on processed groundnuts are lower than those on unprocessed groundnuts. Second, when different markets are compared, the US ranks first in terms of protecting unprocessed groundnuts, followed by India; but India imposes the highest tariff on unprocessed groundnuts followed by China. Tariff escalation is partially observed for palm oil in Brazil, China, and the EU. Again, India is an exception as it has the highest levels of tariffs, which are higher on unprocessed than processed palm oil (Figure 4.37c). Finally, soya oil exhibits tariff escalations (at low levels) in China and the United States.

Hence, to sum up, substantial heterogeneity can be observed for different markets and different value chains, with tariff escalation mainly in sugar, rapeseed, and cassava; to a lesser extent in palm oil and soya; and tariff abatement in groundnut oil.

Figure 4.37 Weighted average tariff rate applied to vegetable oils, by products and degree of processing, 2016

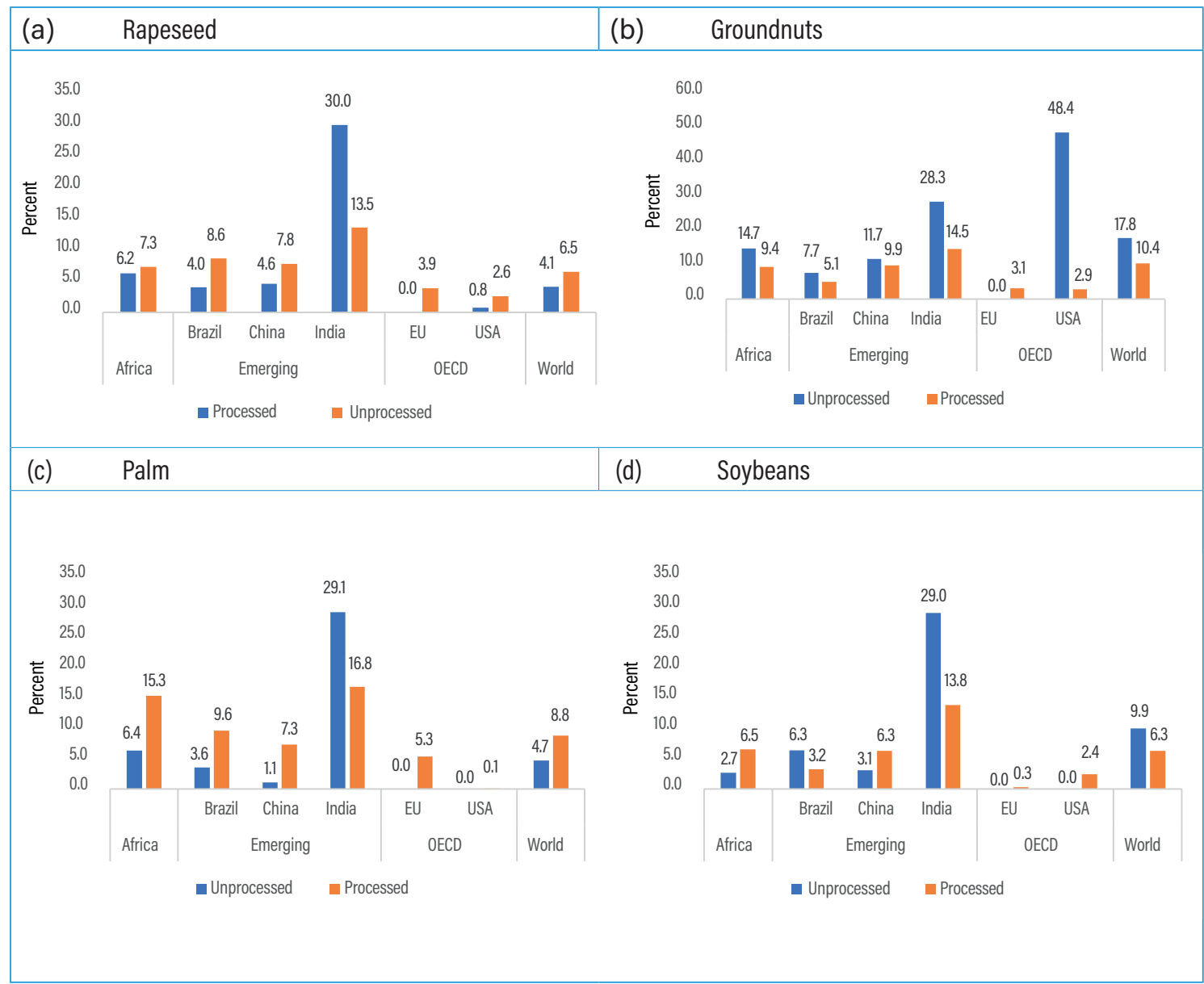

Source: Authors' elaboration using MAcMap-HS6. 


\section{Domestic support}

The agriculture sector is not only characterized by high tariffs and tariff escalations in the main markets, but it also faces several nontariff measures, as highlighted in Chapter 2. These nontariff measures range from sanitary and phytosanitary measures to technical barriers to trade to export-related measures, including domestic support (Dimaranan et al. 2004; Anderson and Martin 2005; Hertel and Keeney 2006). We focus in this section on the domestic support provided in the same set of OECD and emerging countries. First, domestic support is high in general and includes several tools such as production quotas, producer price guarantees, processing loans, regulated consumer prices, and state protection and/or intervention through ownership or investment in domestic industries. Given this heterogeneity in tools, we will adopt the World Trade Organization (WTO) classification that uses a traffic light analogy for categorizing measures as trade distorting or not trade distorting (Box 4.1). Using the most recent WTO notifications, we compiled the domestic support data for each product and for different boxes.

Generally speaking, the largest domestic support is provided in China followed by the US and the EU. The lion's share of this support is provided through the "green box," which includes programs that are non-trade-distorting, since there is no limit on this spending. This includes, among other measures, budget allocations for research programs and research activities at agricultural institutes, training services, and infrastructure services. Spending under the green box represents 90 percent of total agricultural support for China and the US and 83 percent for the EU. These figures are lower for India and Brazil, with shares amounting to 41 percent and 58 percent, respectively. Most of the sectors can benefit from this spending because it deals with cross-cutting issues. Yet, in some cases, these measures can be specific such as, in China, where outlays on public stockholdings of wheat, maize, rice, vegetable oils, and sugar for food security purposes equivalent to US $\$ 17.5$ billion are categorized as green box measures.

Table 4.5 shows that only two countries have notified outlays under the "blue box," namely China and the EU. Outlays under this box include programs that are market-distorting but production-limiting. While the share of support under the blue box amounts to 2 percent for China, it represents 6 percent for the EU. The EU supports sugar with US\$201 million and cereals with US\$108 million. Indeed, the EU sugar market had been one of the most heavily regulated markets in the agrifood sector for 50 years (Poonyth et al. 2005), until the EU quota regime ended in September 2017. It is important to note that the EU, being a large importer of cane sugar, grants duty-free access to the EU market to developing countries under the Everything but Arms agreement.

As for product-specific support, different schemes are observed. First, it is important to note that most of our countries of interest support several products in a de minimis way. For developed countries, this means that spending is less than 5 percent of the value of production. The de minimis threshold is 10 percent for most developing countries, except for China where it is 8.5 percent of the value of agricultural production. This is the case of rice and wheat in China; rice, maize, soybean, and sunflower in the US; sugar in the EU; coarse cereal and rice in Brazil; and coarse cereal, groundnut, rapeseed, soybean, and sunflower in India. Beyond these limits, China provides substantial support for maize (US\$8.7 billion) and soybean (US\$1.1 billion); the US for wheat (US\$0.9 billion) and sugar (US $\$ 1.5$ billion); the EU for wheat (US $\$ 2.4$ billion); and India for rice (US\$5 billion). Yet, it is also important to note that such interventions can significantly distort prices. Indeed, Elobeid and Beghin (2006), using a partial equilibrium international sugar model calibrated on 2002 data, found that the removal of trade distortions alone induces a 27 percent price 
increase, while the removal of all trade and production distortions induces a 48 percent increase in 2011/2012 relative to the baseline.

The remaining part of the total support includes development programs for India and Brazil (44 percent and 4 percent of total support, respectively). These outlays are exempt from the reduction commitment given their special and differential treatment. They can include, among others, input and investment subsidies. Finally, a smaller share (1.8 percent in China, 1 percent in the EU, 6 percent in the US, and 6 percent in India, but 38 percent in Brazil) is allocated to nonspecific product outlays. This category is mainly used to finance subsidies to the purchase of agricultural machinery and tools, debt restructuring, and insurance programs (which is the case of Brazil).

\section{Box 4.1: Domestic support at the World Trade Organization}

The World Trade Organization (WTO) uses a traffic light analogy for domestic support programs.

- Green box programs are minimally or nontrade distorting and are not subject to any spending limits.

- Blue box programs are described as market-distorting but production-limiting. Payments are based on either a fixed area or yield or a fixed number of livestock and are made on less than 85 percent of base production. Thus, blue box programs are not subject to spending limits.

- Amber box programs are the most market-distorting programs and are subject to strict aggregate annual spending limits. They are cumulatively measured by the aggregate measure of support (AMS) subject to the de minimis exemption.

- De minimis exemptions are spending that is sufficiently small (less than 5 percent of the value of production for developed countries, less than 10 percent for developing countries, and less than 8.5 percent for China) - relative to either the value of a specific product or total production - to be deemed benign.

- Prohibited programs include certain types of export and import subsidies and nontariff trade barriers that are not explicitly included in a country's WTO schedule or identified and accepted in the WTO legal texts.

Source: WTO website.

To conclude, this chapter shows that (un)competitiveness of some value chains in Africa can be explained either by supply-side factors (lack of comparative advantage) or demand-side factors (tariff escalation and domestic support for some products). In fact, African economies are still not well-positioned in agrifood value chains. While a very few of them are able to move up the value chains and become competitive at stages of product processing, the majority appear to be competitive only in the export of raw products. Clearly, unprocessed products face a lower rate of protection as tariff escalation is most pronounced in sugar, rapeseed, and cassava, followed by palm oil and soybeans. 
Table 4.5. Domestic support in different markets

\begin{tabular}{|c|c|c|c|c|c|c|c|c|c|c|}
\hline & \multicolumn{2}{|c|}{ China } & \multicolumn{2}{|c|}{ EU } & \multicolumn{2}{|c|}{ USA } & \multicolumn{2}{|c|}{ India } & \multicolumn{2}{|r|}{ Brazil } \\
\hline Issued & $14-12-18$ & & $12-04-19$ & & $24-09-18$ & & $31-03-20$ & & $19-02$ & \\
\hline Period & 2016 & & 2016 & & 2016 & & 2018 & & 2018 & \\
\hline Green box & $198,962.10$ & & $70,915.10$ & & $119,492.00$ & & $22,481.60$ & & 1,590 & \\
\hline Blue box & $5,915.20$ & & $5,334.70$ & & 0 & & 0 & & 0 & \\
\hline Cereals & 0 & & 108 & & 0 & & 0 & & 0 & \\
\hline Oilseeds & 0 & & 2.2 & & 0 & & 0 & & 0 & \\
\hline Sugar beet & 0 & & 200.9 & & 0 & & 0 & & 0 & \\
\hline $\begin{array}{l}\text { Development } \\
\text { programs }\end{array}$ & 0 & & 0 & & 0 & & $24,184.50$ & & 108.3 & \\
\hline Current Total AMS & $12,327.30$ & & $7,982.20$ & & $3,830.00$ & & $5,005.00$ & & 0 & \\
\hline Product-specific & & & & & & & & & & \\
\hline Cereals & & & & & & & & & & \\
\hline Coarse cereal & 0 & de minimis & 0 & de minimis & 0 & de minimis & 9.6 & de minimis & 91.5 & de minimis \\
\hline Rice & $4,210.60$ & de minimis & 0 & de minimis & 86.2 & de minimis & $5,005.00$ & $5,005.00$ & 9.5 & de minimis \\
\hline Maize & $8,662.10$ & $8,662.10$ & 0 & de minimis & $2,344.80$ & de minimis & 0 & de minimis & 0 & de minimis \\
\hline Wheat & $2,960.60$ & de minimis & $2,461.50$ & $2,461.50$ & 911.5 & 911.5 & -30.5 & de minimis & 0 & de minimis \\
\hline Sugar & 0 & de minimis & 2.8 & de minimis & $1,517.30$ & $1,517.30$ & 0 & de minimis & 0 & de minimis \\
\hline Vegetable oils & & & & & & & & & & \\
\hline Groundnut & 0 & de minimis & 0 & de minimis & 0 & de minimis & 133 & de minimis & 0 & de minimis \\
\hline Rapeseed /Mustard & 0 & de minimis & 0 & de minimis & 0 & de minimis & 76.3 & de minimis & 0 & de minimis \\
\hline Soyabean Yellow & $1,113.60$ & $1,113.60$ & 0 & de minimis & $1,207.20$ & de minimis & 5 & de minimis & 0 & de minimis \\
\hline Sunflower & 0 & de minimis & 0 & de minimis & 32.7 & de minimis & 0.7 & de minimis & 0 & de minimis \\
\hline $\begin{array}{l}\text { Non-product- } \\
\text { specific AMS }\end{array}$ & $3,903.03$ & & $1,211.15$ & & $7,405.1$ & & $3,317.1$ & & 1,046 & \\
\hline $\begin{array}{l}\text { Total domestic } \\
\text { support }\end{array}$ & $221,107.58$ & & $85,443.1$ & & $130,727.1$ & & $54,988.1$ & & 2,745 & \\
\hline
\end{tabular}

Source: Authors' elaboration using the WTO notification system.

Note: All figures are in millions of US dollars. 


\section{Concluding remarks}

The objective of this chapter is to examine the defensive trade interests of African economies. Hence, we analyzed three value chains where African economies have a defensive interest: the cereals value chain with the three major cereals (wheat, maize, rice) plus cassava, the sugar value chain, and the vegetable oils value chain. Our main findings show a lot of heterogeneity for the revealed comparative advantage of the three value chains among African countries. Generally speaking, the comparative advantage of unprocessed products is higher than that of semi-processed and processed ones. In terms of trade policy, a lot of heterogeneity can be observed for different export markets and different value chains, with tariff escalation mainly in sugar, rapeseed, and cassava; to a lesser extent in palm oil and soya; and tariff abatement in groundnut oil. Domestic support is particularly important for maize and soybeans in China, for wheat and sugar in the US, for wheat in the EU, and for rice in India.

It is important to note that addressing trade barriers is not sufficient because many African countries still face several bottlenecks in their own value chains (limited technology, unskilled and informal labor, lack of infrastructure). Hence, helping African countries improve their production capacities to raise the productivity of the agriculture sector, make it more modern, and hence more able to export processed products, is indispensable. More specifically, at the trade policy level, reducing tariff escalation and domestic support is crucial since it will add to the export potential of commodity-exporting African countries. Indeed, as shown by Bouët and Laborde (2018), progress in tackling trade barriers is crucial in preventing a severe reduction in trade volumes and income levels. With the de facto failure of the multilateral negotiations in the WTO's Doha Development Round, such negotiations can take place at the plurilateral level (under Article IX:3). Hoekman and Sabel (2019) argue that an open plurilateral agreement allows groups of countries to explore and develop their potential common interests on regulatory matters.

\section{References}

Anderson, K., and W. Martin, eds. 2005. Agricultural Trade Reform and the Doha Development Agenda. Washington, DC: World Bank.

Aziz, A. A., E. K. Denkyirah, and E. K. Denkyirah. 2017. "Effect of Tariff Escalation on Ghanaian Cocoa Exports: An Empirical Perspective." International Journal of Food and Agricultural Economics 5 (1): 45-65.

Bouët, A., L. Cosnard, and D. Laborde. 2017. "Measuring Trade Integration in Africa." Journal of Economic Integration 32 (4): 937-977.

Bouët, A., and D. Laborde. 2018. "U.S. Trade Wars in the 21st Century with Emerging Countries: Make America and its partners Lose Again." The World Economy 41 (9): 2276-2319.

Conway, G., O. Badiane, and K. Glatzel. 2019. Food for All in Africa: Sustainable Intensification for African Farmers. Washington, DC: International Food Policy Research Institute. 
Dimaranan, B., T. Hertel, and R. Keeney. 2004. "OECD Domestic Support and Developing Countries." In The WTO, Developing Countries and the Doha Development Agenda: Prospects and Challenges for Trade-led Growth, edited B. Guha-Khasnobis, 63-91. London: Palgrave Macmillan.

Elamin, N., and H. Khaira. 2003. "Tariff Escalation in Agricultural Commodity Markets." In FAO Commodity Market Review 2003, 101-120. Rome: FAO.

Elobeid, A., and J. Beghin. 2006. "Multilateral Trade and Agricultural Policy Reforms in Sugar Markets." Journal of Agricultural Economics 57 (1): 23-48.

GRO Intelligence. 2016. "The World's Most Expensive Fertilizer Market: Sub-Saharan Africa." December 2.

Hertel, T. W., and R. Keeney. 2006. "What Is at Stake: The Relative Importance of Import Barriers, Export Subsidies, and Domestic Support." Agricultural Trade Reform and the Doha Development Agenda, edited by K. Anderson and W. Martin, 37-62. New York: Palgrave Macmillan and World Bank.

Hoekman, B., F. Ng, and M. Olarreaga. 2002. Reducing Agricultural Tariffs versus Domestic Support: What's More Important for Developing Countries? Washington, DC: World Bank.

Mitaritonna, C., and F. Traoré. 2017. "Existing Data to Measure African Trade." IFPRI Discussion Paper 1618, International Food Policy Research Institution, Washington, DC.

Narayanan, G. B., and S. Khorana. 2014. "Tariff Escalation, Export Shares and Economy-wide Welfare: A Computable General Equilibrium Approach." Economic Modelling 41: 109-118.

Odjo, S. P., F. Traoré, and C., Zaki. 2019. "Intra-African Trade Integration." In Africa Agriculture Trade Monitor 2019, edited by A. Bouët and S. P. Odjo, 43-70. Washington, DC: International Food Policy Research Institute.

Poonyth, D., P. Westhoff, A. Womack, and G. Adams. 2005. "Impacts of WTO Restrictions on Subsidized EU Sugar Exports." Agricultural Economics 22 (3): 233-245.

UN DESA (United Nations Department for Economic and Social Affairs). 2019. "World Population Prospects 2019: Highlights." New York.

Wiggins, S. 2019. "How Farmer-led Irrigation Can Transform Agriculture in Africa." ODI Insights (blog), August 27, Overseas Development Institute.

Yeats, A. J. 1984. "On the Analysis of Tariff Escalation: Is There a Methodological Bias Against the Interest of Developing Countries?" Journal of Development Economics 15 (1-3): 77-88. 

.

.

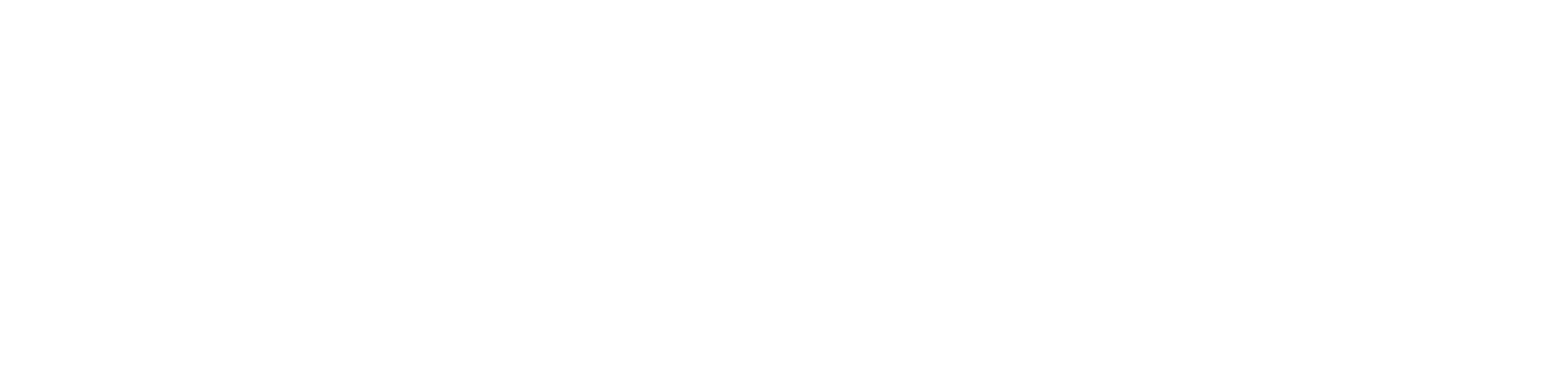
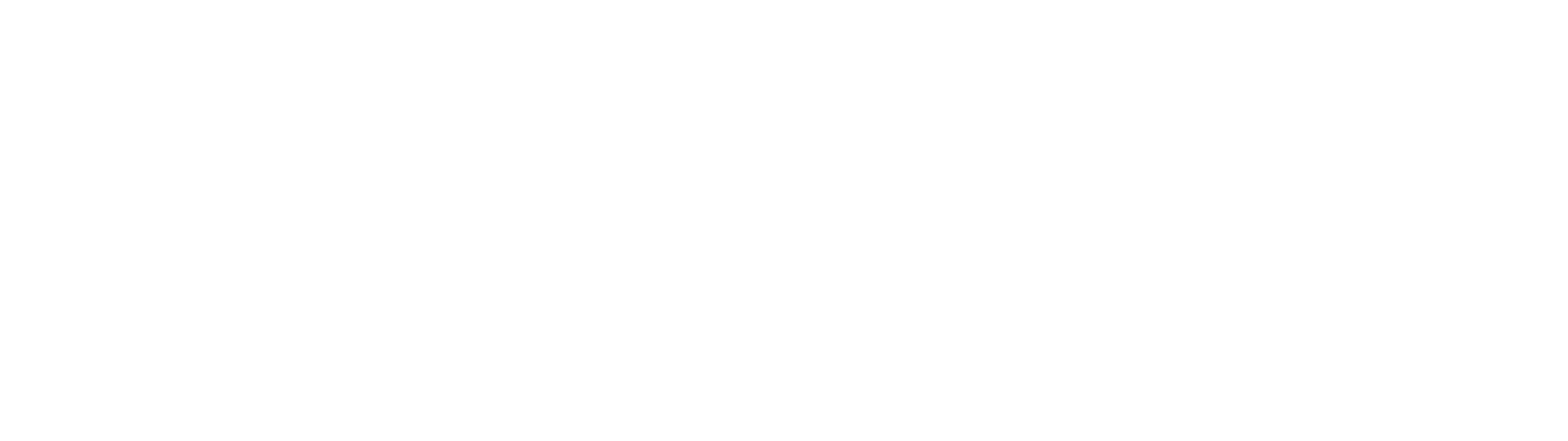